Article

\title{
A Classification of US Wildland Firefighter Entrapments Based on Coincident Fuels, Weather, and Topography
}

\author{
Wesley G. Page *, Patrick H. Freeborn, Bret W. Butler and W. Matt Jolly
}

USDA Forest Service, Rocky Mountain Research Station, Missoula Fire Sciences Lab, Missoula, MT 59808, USA; patrick.h.freeborn@usda.gov (P.H.F.); bret.butler@usda.gov (B.W.B.); matt.jolly@usda.gov (W.M.J.)

* Correspondence: wesley.g.page@usda.gov; Tel.: +1-406-329-4821

Received: 12 September 2019; Accepted: 5 October 2019; Published: 9 October 2019

check for updates

\begin{abstract}
Previous attempts to identify the environmental factors associated with firefighter entrapments in the United States have suggested that there are several common denominators. Despite the widespread acceptance of the assumed commonalities, few studies have quantified how often entrapments actually meet these criteria. An analysis of the environmental conditions at the times and locations of 166 firefighter entrapments involving 1202 people and 117 fatalities that occurred between 1981 and 2017 in the conterminous United States revealed some surprising results. Contrary to general assumptions, we found that at broad spatial scales firefighter entrapments happen under a wide range of environmental conditions, including during low fire danger and on flat terrain. A cluster-based analysis of the data suggested that entrapments group into four unique archetypes that typify the common environmental conditions: (1) low fire danger, (2) high fire danger and steep slopes, (3) high fire danger and low canopy cover, and (4) high fire danger and high canopy cover. There are at least three important implications from the results of this study; one, fire environment conditions do not need to be extreme or unusual for an entrapment to occur, two, the region and site specific context is important, and, three, non-environmental factors such as human behavior remain a critical but difficult to assess factor in wildland firefighter entrapment potential.
\end{abstract}

Keywords: burnover; fire behavior; fire environment; firefighter fatalities

\section{Introduction}

Wildland firefighters in the United States (US) are trained to identify and monitor particular elements of the fire environment in order to assess possible dangers or potential suppression opportunities. Much of the training curriculum that describes what specific aspects of the fire environment to monitor was developed based on the findings from investigations conducted after fatal firefighter entrapment incidents (e.g., [1-3]). Some of the findings from those investigations have also been distilled into safety guidelines for the purpose of helping firefighters recognize dangerous situations [4-7]. An understanding of the shared factors associated with firefighter entrapments has been an important aspect of firefighter training at least since Wilson [5] presented a set of common denominators based on an analysis of 67 fatal and 31 near-fatal fires that occurred in the US between 1926 and 1976 (see below). More recent analyses have acknowledged additional common denominators related to US firefighter entrapments and wildland firefighter fatalities in general, which include high fire danger, communication issues, and a failure to identify adequate escape routes and safety zones $[8,9]$.

Wilson [5] identified four major common denominators of fire behavior on fatal and near-fatal fires: 
1. On relatively small fires or deceptively quiet sectors of large fires.

2. In relatively light fuels, such as grass, herbs, and light brush.

3. When there is an unexpected shift in wind direction or in wind speed.

4. When fire responds to topographic conditions and runs uphill.

Many of the safety guidelines currently used in the US for assessing entrapment potential emphasize the monitoring of specific environmental variables before and during suppression operations [6]. Table 1 displays example fuel, topographic, and weather factors with their respective indicators that are used for determining possible fire behavior-related dangers [10]. Many of the elements listed in Table 1 are associated with the potential for extreme fire behavior, including rapid rates of spread and high fire intensities [11,12]. Extreme fire behavior, as well as what is often referred to as 'blow-up' [13] or 'eruptive' [14] fire behavior, has been linked to firefighter fatalities both in the US and other parts of the world [15-19]. It is thought that a sudden, unexpected increase in rate of spread associated with eruptive fire behavior, particularly on steep slopes and in canyons, limits the ability of firefighters to adapt or escape, thereby increasing the likelihood of entrapment [20-22].

Table 1. Fire environment factors and a partial list of their respective indicators used to assess fire behavior-related dangers as identified in the Look Up, Look Down, Look Around training curriculum [10] and outlined by National Wildfire Coordinating Group [6].

\begin{tabular}{cl}
\hline Factor & Indicator \\
\hline \multirow{3}{*}{ Fuel Characteristics } & - Substantial amounts of cured or curing fine fuel/continuous \\
& - Heavy dead and down \\
& - Unt crown spacing $(<20 \mathrm{ft}[6 \mathrm{~m}])$ \\
& - Steep slopes $\left(>45 \%\left[24^{\circ}\right]\right)$ \\
- Chutes/chimneys/passes/saddles & - Box and narrow canyons \\
\hline Topography & - Wind (speeds above $10 \mathrm{mi} \mathrm{h}^{-1}\left[16 \mathrm{~km} \mathrm{~h}^{-1}\right]$, battling or shifting wind) \\
& - Atmospheric instability (good visibility, inversion lifting) \\
& - Temperature and relative humidity (above normal temperatures, \\
& critically low humidity based on local thresholds)
\end{tabular}

Although the environmental elements related to firefighter entrapments appear to be well characterized, few studies have examined if or how often entrapments conform to these criteria. Part of the problem has been that, until recently, quantitative data related to firefighter entrapments have not been widely available. Page et al. [21] have compiled a database of firefighter entrapments involving burnovers that occurred within the conterminous US (CONUS) since 1979, which includes the location, date, time, number of people involved, number of fatalities, and quality of the location information for entrapments reported from all known sources. The date and location information contained within this database allows entrapments to be linked to historical spatial layers of various environmental data so that a comprehensive dataset of the fire environment during the day of the entrapment and at the entrapment location can be compiled.

The primary purpose of this study is to assemble a dataset of environmental conditions at the times and locations of all known firefighter entrapments involving a burnover that occurred within CONUS and assess any commonalities. It is hypothesized that the majority of entrapments will have fire environment conditions that are similar to those previously reported in other published work, which are indicative of the potential for extreme fire behavior, including high fire danger, steep slopes in narrow canyons, and in light fuel types (i.e., grass and shrub). It is hoped that such an assessment will not only confirm or refute previously established guidelines but also establish a methodology for conducting similar assessments in the future. 


\section{Materials and Methods}

\subsection{Firefighter Entrapments}

All known firefighter entrapments that occurred within CONUS from 1979 to 2017 were obtained from the Fire Sciences Lab Merged Entrapment Database (https://www.wfas.net/entrap/, accessed on 17 July 2019) [21]. Those entrapments listed as burnovers (excluding near-misses and close calls) that had accurate location information were extracted from the full dataset and used for subsequent analysis. The data fields of interest included the latitude and longitude of the entrapment location, the incident name, the date and time that the entrapment occurred, the total number of people involved, the number of fatalities, the incident phase (management activity) during the entrapment, and the type of resource(s) involved. The incident phase was categorized as: (i) initial attack, the time when the first resources arrived on the fire to begin operations, usually within the first $24 \mathrm{~h}$ after detection and response, (ii) extended attack, if initial attack forces fail to contain or control the fire, it transitions to extended operations that may last for several weeks, and (iii) prescribed fire, those incidents where the fire was intentionally ignited to meet various objectives in accordance with all applicable laws and regulations [23]. Note that if prescribed fires were declared escaped at the time of entrapment, then the incident phase was categorized as initial or extended attack. The type of resource(s) involved were defined as follows: (i) Dozer, tracked vehicles with a front mounted blade usually used to construct mineral soil fireline, (ii) Engine, a vehicle with water, hose, a pump, and crewmembers, which is used to suppress fires, (iii) Equipment, includes other miscellaneous vehicles used to construct fireline, such as tractor plows, (iv) Hand Crew, a group of individuals who are organized and supervised as a team for the purpose of conducting wildland fire operations, and (v) Overhead, includes personnel assigned in supervisory positions [23]. Those instances where more than one resource type was involved in an entrapment were categorized as involving multiple resources.

\subsection{Environmental Variables}

Several dynamic (varying over time) and static environmental datasets representing different fuel, topographic, and fire danger conditions were collected for the day and location that each entrapment occurred. Initially, a large set of environmental variables and transformations of those variables were included in the analysis. These encompassed the various climatic factors available from the Parameter-elevation Regressions on Independent Slopes Model (PRISM) [24], the topographic and fuel information from the Landscape Fire and Resource Management Tools (LANDFIRE) [25], Normalized Difference Vegetation Index (NDVI) data from the NOAA Center for Satellite Applications and Research [26], and historical fire danger information from Jolly et al. [27]. Additional transformations of those variables were also initially included in the analysis, such as ratios of slope steepness and elevation within different sized buffers around the entrapment locations, relative greenness [28], and variables for assessing the shape of the landscape, such as the Topographic Position Index [29]. Not surprisingly, many of the environmental variables were highly correlated (e.g., relative greenness vs. proportion of maximum NDVI, climate class vs. average annual precipitation, and slope steepness vs. standard deviation of slope/elevation), thus only those variables that had Pearson's correlation coefficients of less than 0.7 were retained for further analysis (Table 2).

In this study, surrogates for the fire weather and fuel conditions at the times and locations of the firefighter entrapments were utilized. Daily fire weather was summarized using fire danger indices from the National Fire Danger Rating System (NFDRS) [30], including the Energy Release Component (ERC) and the Burning Index (BI), rescaled to their local, historical percentile values (ERC' and BI', respectively). The rescaled fire danger indices were utilized as opposed to the raw fire weather variables (e.g., relative humidity) for several reasons. Normalized fire danger indices are comparable across locations with different fuel types and climatologies, they do not require high temporal resolution (i.e., less than daily) of the underlying individual weather variables that are often not available for historical 
time periods, and wildland firefighters are familiar with their interpretation and already utilize them to make fire management decisions.

Table 2. Environmental variables used to assess commonalties among US wildland firefighter entrapments across the conterminous United States (CONUS). Dynamic variables vary either daily, i.e., the National Fire Danger Rating System (NFDRS) components [30], or weekly, i.e., the Normalized Difference Vegetation Index (NDVI) proportion of maximum values. Some of the data were calculated using a Geographic Information System (GIS).

\begin{tabular}{|c|c|c|}
\hline Variable & Description & Source \\
\hline \multicolumn{3}{|l|}{ Dynamic } \\
\hline $\begin{array}{l}\text { Burning Index percentile } \\
\qquad\left(\mathrm{BI}^{\prime}\right)\end{array}$ & $\begin{array}{l}\text { NFDRS output designed to represent the difficulty of controlling } \\
\text { a fire, numerically it is equivalent to potential flame length. } \\
\text { Daily, CONUS-wide, } 4 \mathrm{~km} \text { gridded values from a } 39-\mathrm{yr} \\
\text { climatology (1979-2017) have been normalized and converted to } \\
\text { percentiles assuming a constant fuel model (G). Potential values } \\
\text { are in decimal form and range of } 0 \text { to } 1 \text { where } 1 \text { is the } \\
\text { 100th percentile. }\end{array}$ & Jolly et al. [27] \\
\hline $\begin{array}{c}\text { Energy Release } \\
\text { Component percentile } \\
\left(\mathrm{ERC}^{\prime}\right)\end{array}$ & $\begin{array}{l}\text { NFDRS output numerically equivalent to the potential available } \\
\text { energy released per unit area in the flaming zone. Daily, } \\
\text { CONUS-wide, } 4 \mathrm{~km} \text { gridded values from a } 39 \text {-yr climatology } \\
\text { (1979-2017) have been normalized and converted to percentiles } \\
\text { assuming a constant fuel model (G). Potential values are in } \\
\text { decimal form and range from } 0 \text { to } 1 \text { where } 1 \text { is the } \\
\text { 100th percentile. }\end{array}$ & Jolly et al. [27] \\
\hline $\begin{array}{l}\text { Proportion of maximum } \\
\text { NDVI (propMax) }\end{array}$ & $\begin{array}{l}\text { Smoothed NDVI values from across CONUS ( } 4 \mathrm{~km} \text { grid spacing) } \\
\text { that are produced weekly based on data from the AVHRR }{ }^{1} \\
\text { (1981-2012) and VIIRS }{ }^{2} \text { (2013-2017) satellites. The gridded } \\
\text { weekly values are divided by the maximum value obtained over } \\
\text { the entire period (1981-2017) at each location to obtain the } \\
\text { proportion of maximum value. Potential values range from } 0 \\
\text { to } 1 .\end{array}$ & NOAA [26] \\
\hline
\end{tabular}

\begin{tabular}{|c|c|c|}
\hline Beer's aspect (BA) & $\begin{array}{l}\text { Aspect (in degrees), from LANDFIRE [25], transformed } \\
\text { following Beers et al. [31]. Values have } 30 \mathrm{~m} \text { resolution and are } \\
\text { symmetric about a SW to NE line where } 0 \text { represents a southwest } \\
\text { aspect }\left(225^{\circ}\right) \text { and } 2 \text { represents a northeast aspect }\left(45^{\circ}\right) \text {. }\end{array}$ & GIS \\
\hline $\begin{array}{l}\text { Maximum NDVI } \\
\quad(\operatorname{maxNDVI})\end{array}$ & $\begin{array}{l}\text { The maximum observed NDVI value at each } 4 \mathrm{~km} \text { grid cell } \\
\text { across CONUS from } 1981 \text { to } 2017 \text { from NOAA [26]. }\end{array}$ & GIS \\
\hline slope & $\begin{array}{l}\text { Change in elevation over a specific area or the incline of a surface. } \\
\text { Values have } 30 \mathrm{~m} \text { resolution and are reported in degrees. }\end{array}$ & LANDFIRE [25] \\
\hline slope ratio & $\begin{array}{l}\text { The ratio of the standard deviation of slope within a } 500 \mathrm{~m} \\
\text { radius to the standard deviation of slope within a } 5 \mathrm{~km} \text { radius } \\
\text { around each cell. Values have } 30 \mathrm{~m} \text { resolution. }\end{array}$ & GIS \\
\hline $\begin{array}{l}\text { Topographic Position } \\
\text { Index (TPI) }\end{array}$ & $\begin{array}{c}\text { The difference between a cell elevation value, from } \\
\text { LANDFIRE [25], and the average elevation of the neighborhood } \\
\text { around that cell. Positive values indicate the cell is higher than } \\
\text { its surroundings and negative values indicate that it is lower. In } \\
\text { this case, the neighborhood is a } 2 \mathrm{~km} \text { square around each cell. } \\
\text { Values have } 30 \mathrm{~m} \text { resolution. }\end{array}$ & Jenness [29] \\
\hline $\begin{array}{l}\text { 30-yr average annual } \\
\text { precipitation(precip) }\end{array}$ & $\begin{array}{l}\text { Average annual precipitation (1981-2010) across CONUS (800 m } \\
\text { grid spacing). Values are reported in } \mathrm{mm} \mathrm{yr}^{-1} .\end{array}$ & PRISM [24] \\
\hline
\end{tabular}

To represent vegetation conditions on a continuous scale, the 30-yr average annual precipitation (precip) and the maximum NDVI value recorded over a 36-yr period (maxNDVI) were extracted and calculated, respectively. Both annual precipitation and NDVI are known to be related to plant productivity, canopy cover [32,33], and both have previously been used to classify vegetation types [34]. Additionally, relative greenness as represented by the ratio of the weekly smoothed NDVI value to the maximum potential NDVI value (propMax) was used as a surrogate for the level of curing [35]. 


\subsection{Data Compilation}

The relevant values for all of the environmental variables were extracted at the location of each entrapment either on the day the entrapment occurred (i.e., the normalized NFDRS indices) or the week prior to the entrapment (i.e., NDVI and propMax). The entrapments that occurred prior to 1981 did not have NDVI values available from the data source utilized, thus only 166 of the original entrapments that happened between 1981 and 2017 were used in the analysis.

Additional data from the Fire Occurrence Database (FOD) [36] and the Monitoring Trends in Burn Severity (MTBS) database [37] were retrieved and compiled for subsequent analysis. These databases include the reported ignition location, discovery date, and containment date for all fires reported by US wildland fire management agencies from 1992 to 2017 (FOD) and the final perimeters of all large fires from 1984 to 2017 greater than 405 ha (1000 ac) in the western US and 202 ha (500 ac) in the eastern US (MTBS). Applicable values for all environmental variables were assigned to each fire in the FOD based on the date of discovery and the reported ignition location. The MTBS large fire perimeters were used to clip geospatial layers of the environmental variables to each fire perimeter in a Geographic Information System for each day from the discovery to containment date. Note that only the final fire perimeter was available in the MTBS database, thus the final fire perimeter was used to clip all geospatial layers for each day the fire was not contained.

\subsection{Data Analysis}

The compiled dataset was analyzed by viewing the distribution of values for each variable and evaluating the results of a clustering-based algorithm. Specifically, the range of values associated with each environmental variable were viewed by calculating the percentile rank of each observation using a cumulative distribution function and plotting the results. Note that the sampling unit for all analyses was an entrapment incident, regardless of the number of people or fatalities involved. However, the cumulative distributions of the number of people and fatalities were also computed for comparison. The data were also subjected to a clustering analysis to determine if patterns or clusters, i.e., common characteristics, existed within the data. The raw environmental values were rescaled to standard scores (Z-scores) and the nonparametric clustering techniques in the clues package [38] in $R$ [39] were used to determine the optimal number of clusters based on the Silhouette strength measure index [40]. The similarity measures used to partition the data into clusters included the Euclidean, centroid (k-means [41]), and medoids (Partition Around Medoids (PAM) [42]) methods. The method that produced the highest average Silhouette value was used for further analysis.

Once the data were partitioned into clusters the nonparametric Kruskal-Wallis test [43] was employed to determine if the values of the environmental variables for each cluster came from identical populations. If sufficient evidence existed to suggest that at least one of the clusters had values that came from a different population (i.e., $\alpha \leq 0.05$ ) then a post-hoc multiple comparison test (Dunn's test [44]) using the Benjamini-Hochberg adjustment [45] was employed to determine which clusters differed. Statistical tests of independence and association in the $v c d$ package in $R$ [46] were also utilized to assess the relationships between the cluster types and other categorical variables, including the Geographic Area Coordination Center (GACC) in which the entrapment occurred, incident phase, and type of resource(s) affected. The likelihood ratio test was applied to assess independence between the categorical variables and Cramér's V [47] was employed to determine the strength of the association. To visualize the specific associations between categorical variables, association plots [48] were used, which display standardized deviations of observed from expected values.

A Random Forests analysis [49] was also utilized to both assess the relative importance of each environmental variable on predicting cluster type and to predict cluster type for all fires in the FOD and within each large perimeter obtained from the MTBS database. The Gini splitting rule with at least three variables per split and 1000 trees were used to create the Random Forest model using the randomForestSRC package in $R$ [50]. To aid in identifying important thresholds for classifying cluster type, a decision tree using the rpart package in $R$ [51] was also employed. Finally, to assess 
the frequency of the entrapment clusters through space and over time, the Random Forests model was used to predict cluster type across CONUS for each day from 1981 to 2017 that had both the appropriate NFDRS (i.e., BI' and ERC') and NDVI values available. The results of these predictions were summarized by displaying the proportion of days in which both the dynamic variables (fire danger and NDVI) and static variables (i.e., topography) were classified as the same cluster type.

\section{Results}

\subsection{General Characteristics}

The compiled dataset included a total of 166 separate entrapment incidents involving 1202 people (injured and non-injured) and 117 fatalities. The number of incidents were nearly evenly distributed between initial and extended attack fires, but the majority of people were affected during extended attack fires (Table 3). Entrapments involving Engines occurred most frequently, but the bulk of people involved in entrapments were working on Hand Crews. Entrapments with multiple resource types tended to involve the most people and fatalities per incident, with an average of 27 people and 3 fatalities per incident.

Table 3. Summary of US wildland firefighter entrapments that occurred within CONUS (1981-2017) by incident phase and type of resource involved.

\begin{tabular}{cccc}
\hline Variable & Number of Entrapments & Number of People & Number of Fatalities \\
\hline Incident phase & & & \\
\hline Initial attack & 84 & 310 & 62 \\
Extended attack & 73 & 863 & 52 \\
Prescribed fire & 9 & 29 & 3 \\
\hline Resource type & & & \\
\hline Dozer & 11 & 19 & 4 \\
Engine & 62 & 322 & 6 \\
Equipment & 21 & 32 & 56 \\
Hand Crew & 49 & 560 & 4 \\
Overhead & 14 & 23 & 25 \\
Multiple & 9 & 246 & \\
\hline
\end{tabular}

Approximately $84 \%$ of entrapment incidents, $83 \%$ of people, and $73 \%$ of fatalities took place between the hours of 1300 and 1600 local time, with about $52 \%$ of the incidents happening during the months of July, August, and September (Figure 1).

Across CONUS, firefighter entrapments occurred under a wide range of environmental conditions (Figure 2). Generally, the distribution of entrapment incidents, people, and fatalities were similar among the environmental variables with the following exceptions. Firefighter fatalities tended to concentrate at higher fire danger, more cured fuels, and on steeper slopes. For example, $75 \%$ of entrapment incidents happened when ERC' was greater than the 85th percentile, but the same proportion of fatalities happened when ERC' was greater than the 93rd percentile. Likewise, $75 \%$ of entrapments incidents occurred on slopes steeper than about $2^{\circ}$, but $75 \%$ of fatalities happened on slopes steeper than $7^{\circ}$.

The locations where entrapment incidents took place had both low $\left(<500 \mathrm{~mm} \mathrm{yr}^{-1}\right)$ and high ( $>1500 \mathrm{~mm} \mathrm{yr}^{-1}$ ) annual precipitation (precip, Figure $2 \mathrm{~h}$ ), but the majority happened where precip was less than about $800 \mathrm{~mm} \mathrm{yr}^{-1}$. Similarly, the entrapment locations had maximum potential greenness values (maxNDVI) that ranged from 0.27 to 0.67 , which were mostly concentrated between 0.45 and 0.55 (Figure 2d). The topographic conditions at the entrapment locations also covered a substantial range of values, with slopes ranging in steepness from 0 to $38^{\circ}$ (Figure 2e) and surrounding terrain that was both substantially higher and lower than the entrapment location (Figure $2 \mathrm{~g}$ ). Somewhat 
unique amongst the entrapments was that they tended to occur when the ERC' and BI' values were high, generally greater than the 90th percentile, although entrapments were still recorded at values as low as the 6th percentile for BI' and the 17th percentile for ERC' (Figure 2a).

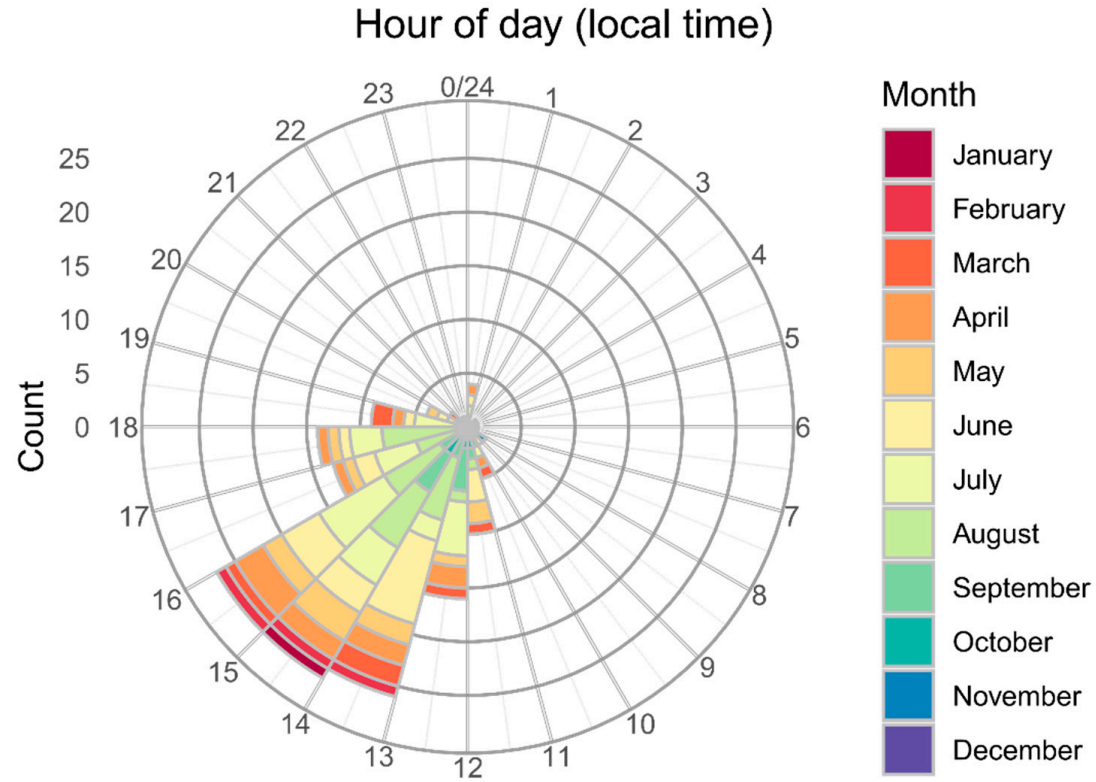

Figure 1. Distribution of 166 US wildland firefighter entrapments that occurred within CONUS (1981-2017) by time of day (local time) and month of the year.
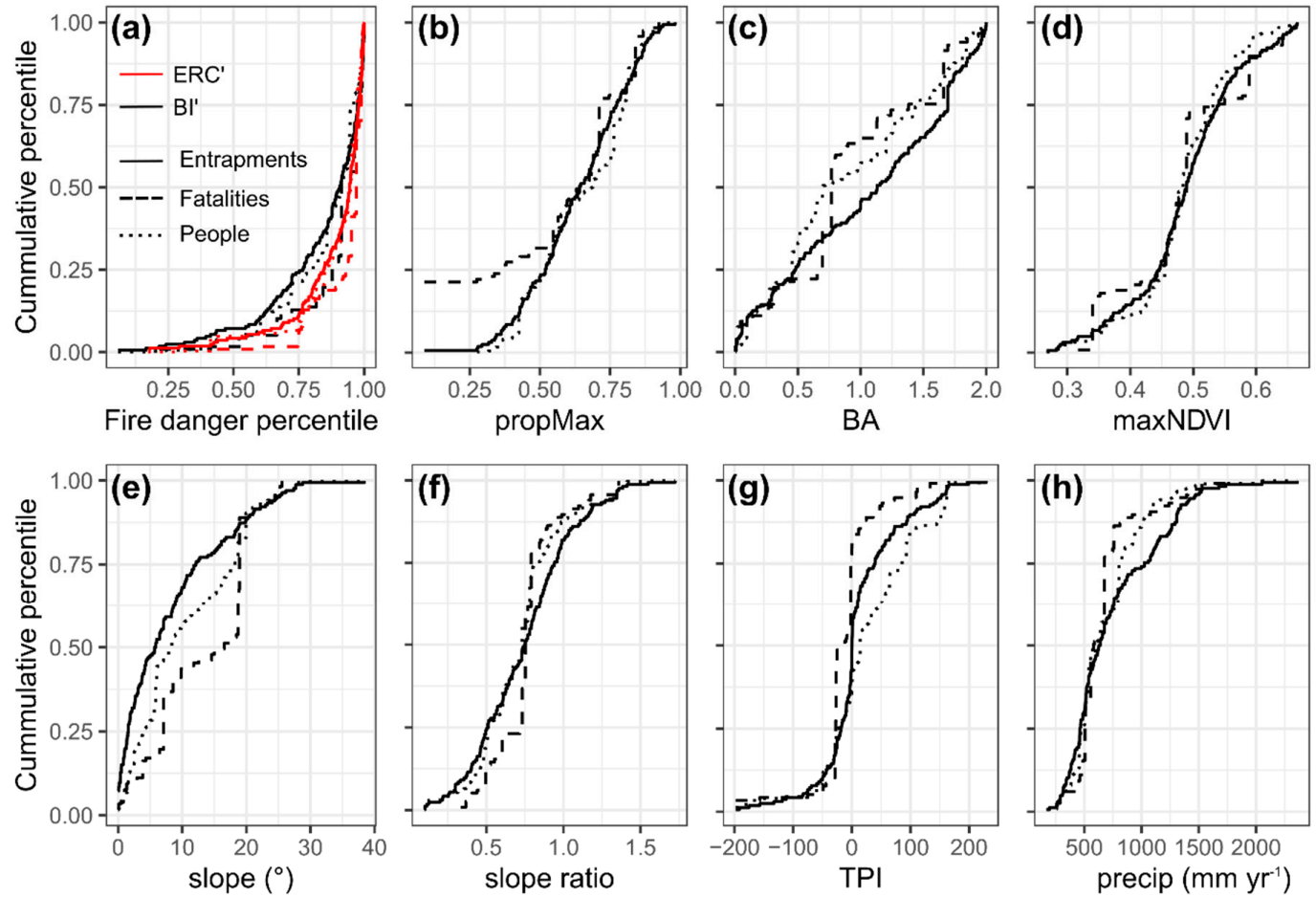

Figure 2. Cumulative percentile distributions of entrapment incidents (solid line), fatalities (dashed line) and people (dotted line) for each of the environmental variables $(\mathbf{a}-\mathbf{h})$ at the times and locations of 166 wildland firefighter entrapments that occurred within CONUS (1981-2017). See Table 2 for variable definitions. 


\subsection{Entrapments Cluster across Several Environmental Variables}

The rescaled environmental data from the firefighter entrapments were optimally partitioned into four clusters based on the Silhouette strength measure index. The average Silhouette value obtained using the Euclidean clustering method was 0.12, while the average Silhouette values for the k-means (centroids) and PAM (medoids) clustering methods were 0.15 and 0.10, respectively; thus, the k-means clustering results were used for all further analyses.

The clustering results indicated that the environmental conditions at the times and locations of the entrapments clustered in specific ways (Figure 3). The maxNDVI and precip variable values were highest for entrapments within cluster 4 and lowest for entrapments within cluster 3. Additionally, cluster 2 entrapments had the steepest slopes while cluster 1 entrapments had the lowest fire danger values (see Figure A1 in Appendix A for cumulative percentile distributions by cluster type). Analysis of the unscaled, raw environmental values confirmed that there were several significant differences among the clusters (Table 4). Specifically, the distribution of values for all the environmental variables, except BA, were significantly different among entrapment clusters. Furthermore, there is evidence to suggest that the clusters represent entrapments with different potential impacts to firefighters as cluster 2 entrapments affected more people per entrapment than cluster 4 entrapments.

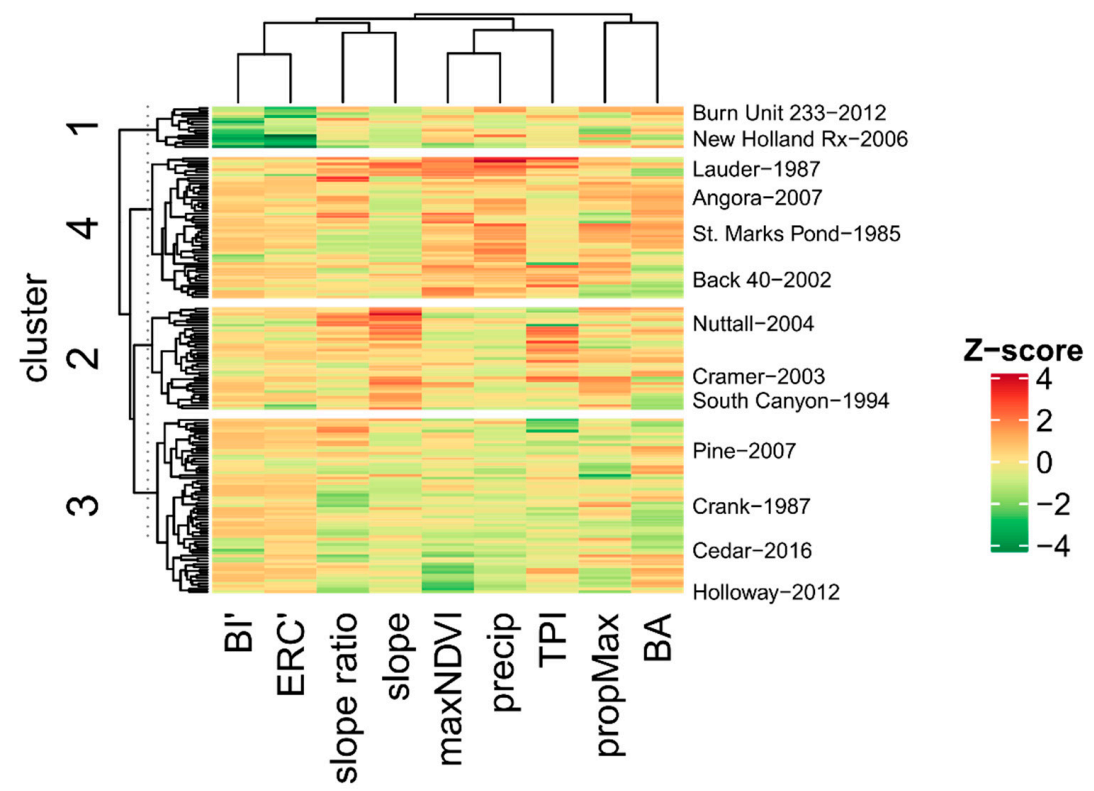

Figure 3. Scaled values (Z-scores) of the nine environmental variables by cluster for each of the 166 firefighter entrapments (1981-2017) used in the analysis. Dendrograms are shown in the margins for the entrapments and environmental variables. Differences in height of the branches in the dendrogram represent differences within and among clusters. Example entrapments (incident name-year of occurrence) for each cluster are also shown in the right margin. See Table 2 for variable definitions.

The Random Forests analysis indicated that a few key environmental variables were important for classifying the entrapment data by cluster (Figure 4). The classification of cluster 1 was most strongly affected by the values of $\mathrm{BI}^{\prime}$ and $\mathrm{ERC}^{\prime}$, cluster 2 was primarily related to slope steepness, and clusters 3 and 4 were predominantly influenced by the precip and maxNDVI values. Scatter plots of these important variables grouped by fire environment type, i.e., fire danger (Figure 5a), fuels (Figure 5b), and topography (Figure 5c) show how the entrapment data cluster in 2D space. Entrapments within cluster 1 tended to occur under relatively low fire danger conditions (i.e., low BI' and ERC' values) while entrapments within clusters 2, 3, and 4 occurred under high fire danger conditions (i.e., high BI' and $E^{\prime} C^{\prime}$ values). Cluster 2 entrapments generally occurred on the steepest slopes. The primary difference between entrapments within clusters 3 and 4 appears to be related to precip and maxNDVI where 
cluster 4 entrapments occurred under higher annual average precipitation and potential greenness than cluster 3 entrapments.

Table 4. Descriptive information for each entrapment cluster along with group comparisons based on the Kruskal-Wallis test [43] followed by multiple comparisons using Dunn's test [44]. Data shown for each cluster are mean \pm standard deviation and the ranges (in round brackets). See Table 2 for definitions of variables, $n$ is sample size. Clusters with common superscript letters are not significantly different by Dunn's test at the $5 \%$ level of significance.

\begin{tabular}{|c|c|c|c|c|c|c|}
\hline \multirow{2}{*}{ Variable } & \multicolumn{4}{|c|}{ Cluster } & \multirow{2}{*}{$X^{2}$} & \multirow{2}{*}{$p$-Value } \\
\hline & $1(n=15)$ & $2(n=37)$ & $3(n=63)$ & $4(n=51)$ & & \\
\hline $\mathrm{BI}^{\prime}$ & $\begin{array}{c}0.42 \pm 0.21^{\mathrm{A}} \\
(0.06-0.81)\end{array}$ & $\begin{array}{c}0.85 \pm 0.11^{\mathrm{B}} \\
(0.55-0.99)\end{array}$ & $\begin{array}{c}0.88 \pm 0.14^{\mathrm{BC}} \\
(0.44-1.0)\end{array}$ & $\begin{array}{c}0.90 \pm 0.12^{\mathrm{C}} \\
(0.47-1.0)\end{array}$ & 42.6 & $<0.001$ \\
\hline $\mathrm{ERC}^{\prime}$ & $\begin{array}{l}0.54 \pm 0.21^{\mathrm{A}} \\
(0.17-0.79)\end{array}$ & $\begin{array}{c}0.89 \pm 0.11^{\mathrm{B}} \\
(0.54-0.99)\end{array}$ & $\begin{array}{c}0.94 \pm 0.06^{\mathrm{C}} \\
(0.75-1.0)\end{array}$ & $\begin{array}{c}0.92 \pm 0.08^{\mathrm{BC}} \\
(0.60-1.0)\end{array}$ & 42.1 & $<0.001$ \\
\hline propMax & $\begin{array}{c}0.59 \pm 0.20^{\mathrm{A}} \\
(0.28-0.87)\end{array}$ & $\begin{array}{c}0.69 \pm 0.15^{\mathrm{AB}} \\
(0.36-0.94)\end{array}$ & $\begin{array}{c}0.56 \pm 0.15^{\mathrm{A}} \\
(0.09-0.90)\end{array}$ & $\begin{array}{c}0.70 \pm 0.16^{\mathrm{B}} \\
(0.29-0.98)\end{array}$ & 26.1 & $<0.001$ \\
\hline BA & $\begin{array}{c}1.2 \pm 0.58 \\
(0.05-1.99)\end{array}$ & $\begin{array}{c}1.1 \pm 0.62 \\
(0.04-1.99)\end{array}$ & $\begin{array}{l}0.9 \pm 0.64 \\
(0.0-1.98)\end{array}$ & $\begin{array}{c}1.2 \pm 0.68 \\
(0.0-2.0)\end{array}$ & 4.9 & 0.182 \\
\hline $\operatorname{maxNDVI}$ & $\begin{array}{c}0.48 \pm 0.07^{\mathrm{A}} \\
(0.32-0.59)\end{array}$ & $\begin{array}{c}0.48 \pm 0.05^{\mathrm{A}} \\
(0.37-0.61)\end{array}$ & $\begin{array}{c}0.43 \pm 0.07^{\mathrm{B}} \\
(0.27-0.55)\end{array}$ & $\begin{array}{c}0.57 \pm 0.06^{\mathrm{C}} \\
(0.44-0.67)\end{array}$ & 78.1 & $<0.001$ \\
\hline slope $\left(^{\circ}\right)$ & $\begin{array}{c}3 \pm 3.3^{\mathrm{A}} \\
(0-13)\end{array}$ & $\begin{array}{c}18 \pm 7.1^{\mathrm{B}} \\
(6-38)\end{array}$ & $\begin{array}{c}5 \pm 4.4^{\mathrm{A}} \\
(0-20)\end{array}$ & $\begin{array}{c}6 \pm 7.3^{\mathrm{A}} \\
(0-28)\end{array}$ & 66.7 & $<0.001$ \\
\hline slope ratio & $\begin{array}{c}0.68 \pm 0.30^{\mathrm{AB}} \\
(0.10-1.27)\end{array}$ & $\begin{array}{c}0.84 \pm 0.25^{\mathrm{AB}} \\
(0.40-1.38)\end{array}$ & $\begin{array}{c}0.63 \pm 0.30^{\mathrm{A}} \\
(0.10-1.32)\end{array}$ & $\begin{array}{c}0.86 \pm 0.31^{\mathrm{B}} \\
(0.37-1.72)\end{array}$ & 17.8 & $<0.001$ \\
\hline TPI & $\begin{array}{l}5 \pm 28^{\mathrm{AB}} \\
(-44-86)\end{array}$ & $\begin{array}{c}42 \pm 86^{\mathrm{A}} \\
(-199-199)\end{array}$ & $\begin{array}{l}-20 \pm 51^{\mathrm{B}} \\
(-192-99)\end{array}$ & $\begin{array}{c}30 \pm 63^{\mathrm{A}} \\
(-157-229)\end{array}$ & 27.6 & $<0.001$ \\
\hline precip $\left(\mathrm{mm} \mathrm{yr}^{-1}\right)$ & $\begin{array}{l}709 \pm 389^{\mathrm{A}} \\
(311-1519)\end{array}$ & $\begin{array}{l}602 \pm 191^{\mathrm{A}} \\
(266-1098)\end{array}$ & $\begin{array}{l}499 \pm 168^{\mathrm{A}} \\
(171-1142)\end{array}$ & $\begin{array}{c}1185 \pm 339^{\mathrm{B}} \\
(619-2362)\end{array}$ & 90.1 & $<0.001$ \\
\hline $\begin{array}{l}\text { People per } \\
\text { entrapment }\end{array}$ & $\begin{array}{c}6 \pm 13^{\mathrm{AB}} \\
(1-50)\end{array}$ & $\begin{array}{c}12 \pm 18^{\mathrm{A}} \\
(1-89)\end{array}$ & $\begin{array}{c}6 \pm 7^{\mathrm{AB}} \\
(1-41)\end{array}$ & $\begin{array}{l}6 \pm 13^{\mathrm{B}} \\
(1-68)\end{array}$ & 10.3 & 0.016 \\
\hline $\begin{array}{c}\text { Fatalities per } \\
\text { entrapment }\end{array}$ & $\begin{array}{c}0.1 \pm 0.35 \\
(0-1)\end{array}$ & $\begin{array}{c}0.8 \pm 2.41 \\
(0-14)\end{array}$ & $\begin{array}{c}1.1 \pm 4.0 \\
(0-25)\end{array}$ & $\begin{array}{l}0.3 \pm 0.58 \\
(0-2)\end{array}$ & 1.6 & 0.653 \\
\hline
\end{tabular}

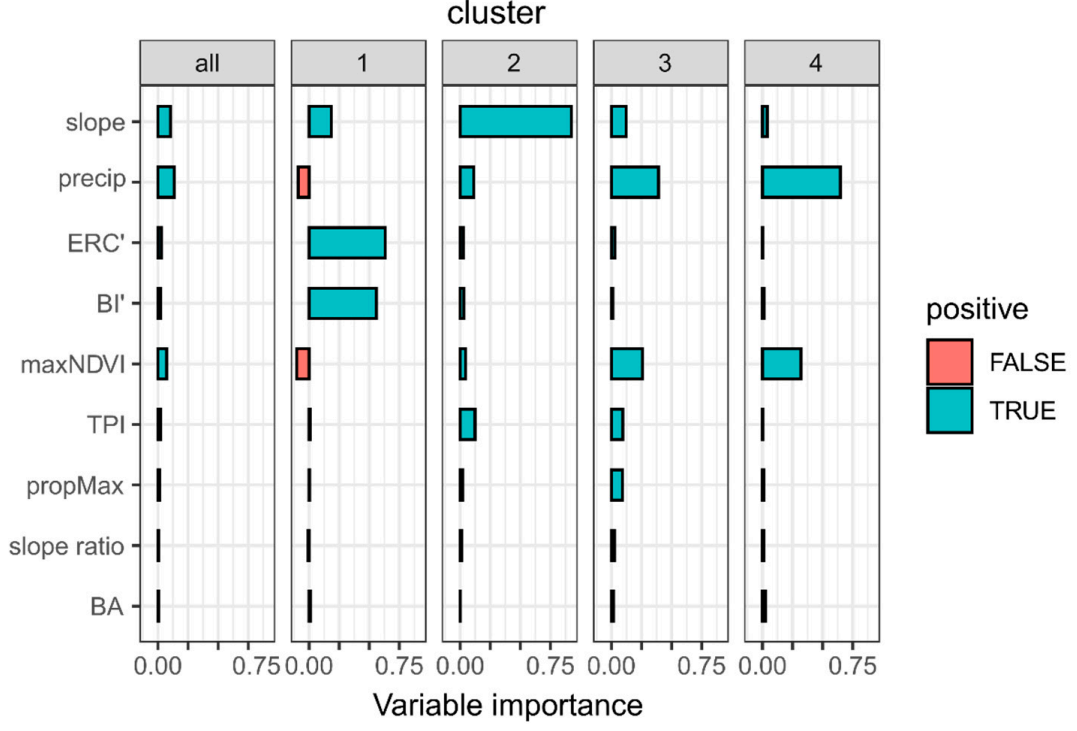

Figure 4. Relative importance of the various environmental variables used to classify firefighter entrapments by cluster using Random Forests [49]. A negative value indicates that the variable had a detrimental impact on the classification. See Table 2 for variable definitions. 

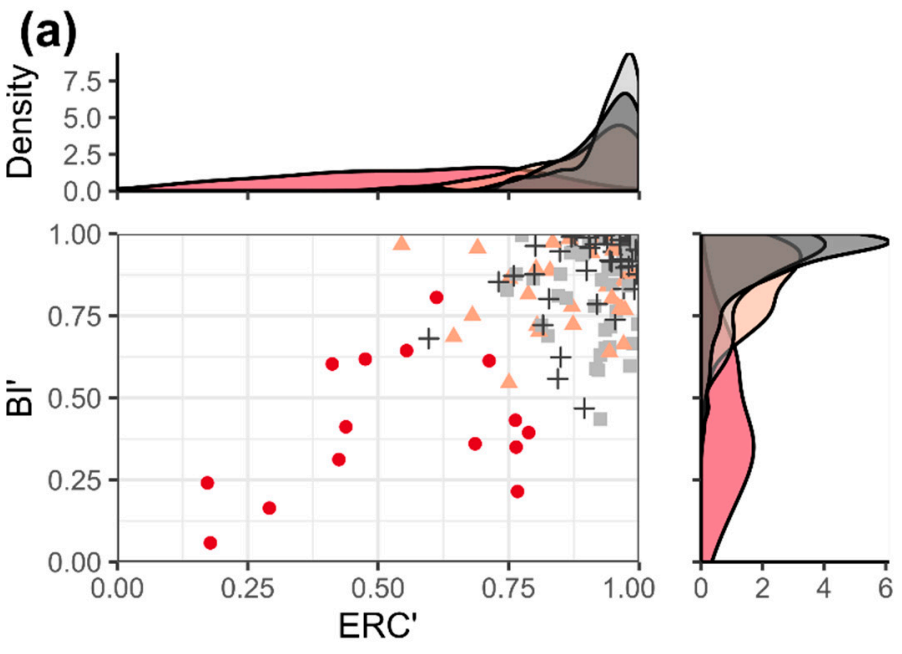

(b)
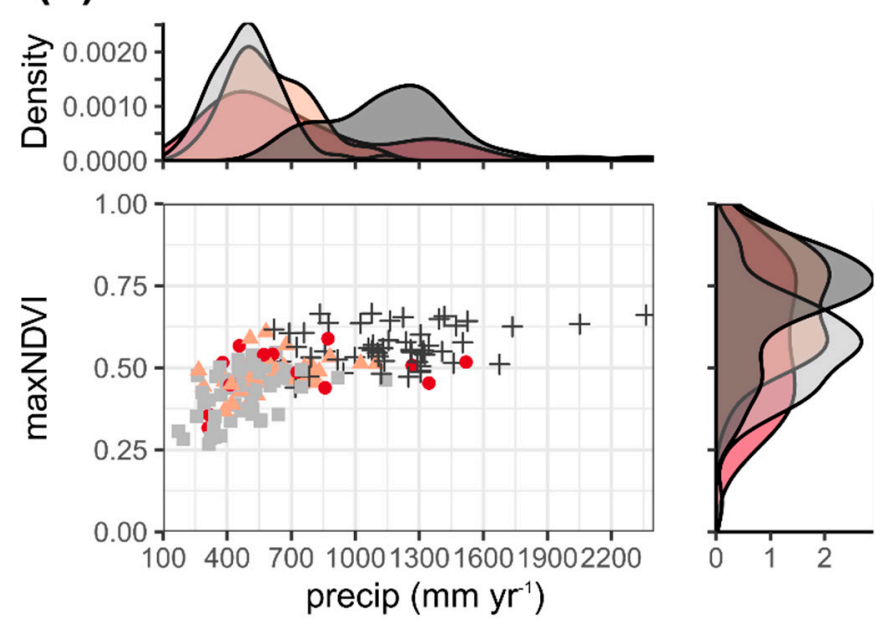

cluster

- 1

$\triangle \quad 2$

- 3

$+4$

\section{(c)}
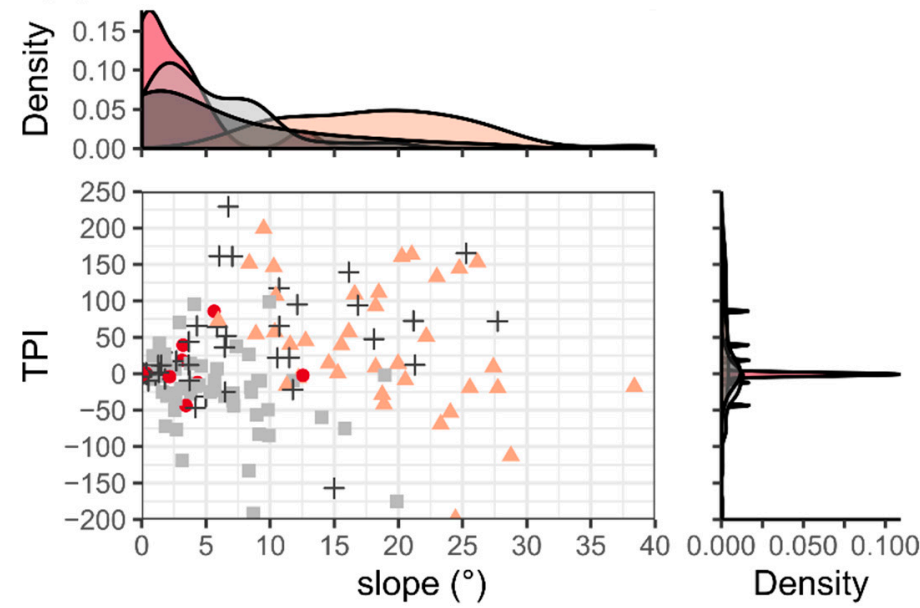

Figure 5. Scatter plots of environmental variables at the time and location of 166 firefighter entrapments (1981-2017). Plots representing the corresponding kernel densities by cluster are also shown for each axis. The variables are grouped by fire environment type: (a) fire danger, which includes $\mathrm{BI}^{\prime}$ and $\mathrm{ERC}^{\prime} ;$ (b) fuel related variables, including maxNDVI and precip; and (c) topography related variables, including TPI and slope steepness. See Table 2 for variable definitions. 
The above analysis suggests that it is reasonable to define four entrapment archetypes that typify the environmental conditions associated with firefighter entrapments in the US. The archetypes include (1) cluster 1, low fire danger entrapments (LFD), (2) cluster 2, high fire danger, steep slope entrapments (HFD-SS), (3) cluster 3, high fire danger, low canopy cover entrapments (HFD-LC), and (4) cluster 4, high fire danger, high canopy cover entrapments (HFD-HC). A decision tree developed to classify the entrapments by cluster type using the environmental data helps define specific breakpoints (Figure 6). At locations where precip exceeds $759 \mathrm{~mm} \mathrm{yr}^{-1}$, LFD entrapments tended to occur when the ERC' value was below the 71st percentile. Above the 71st percentile, HFD-SS entrapments occurred where the slope exceeded $19^{\circ}[34 \%]$ and HFD-HC entrapments occurred where slopes were less than $19^{\circ}$ [34\%]. At locations where precip was lower than $759 \mathrm{~mm} \mathrm{yr}^{-1}$, HFD-SS entrapments occurred on slopes steeper than $10^{\circ}$ [18\%], while, on flatter slopes, LFD entrapments occurred when ERC' was less than the 79th percentile. Entrapments within HFD-LC also occurred in drier climates on relatively flat slopes when ERC' was greater than the 79th percentile.

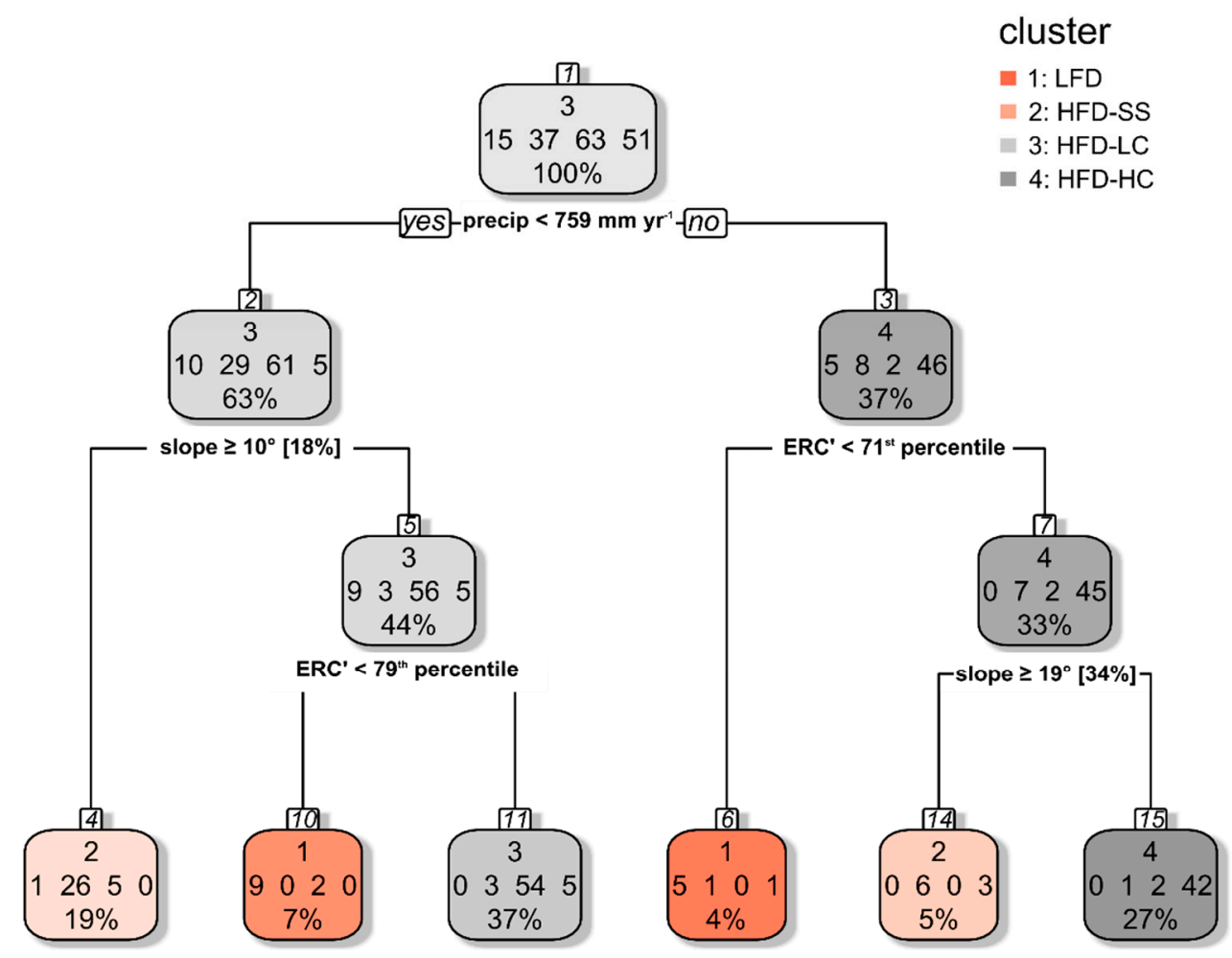

Figure 6. Decision tree used to classify US firefighter entrapments by cluster type. The values within each box, from top to bottom, include the cluster type with the most observations, the number of entrapments by cluster type ( 1 to 4 from left to right), and the percentage of observations that are defined by the particular set of conditions. See Table 2 for variable definitions.

\subsection{Additional Characteristics of Entrapment Clusters}

Several additional non-environmental characteristics associated with the entrapment clusters were identified. The GACC, type of firefighting resource involved, and incident phase were all strongly associated with cluster type (Table 5). Entrapments within LFD were positively associated, i.e., occurred more often than expected, with the Rocky Mountain GACC while entrapments within HFD-HC were positively related to the Southern and northern California (NorthOps) GACCs (Figure 7). Entrapments within HFD-LC were negatively associated, i.e., occurred less than expected, with the Southern GACC. 
Table 5. Additional non-environmental categorical variables associated with US wildland firefighter entrapments (1981-2017). The results from a likelihood ratio test for independence between cluster type and each categorical variable are shown with the associated chi-square statistic $\left(\mathrm{X}^{2}\right)$, degrees of freedom (df), and the strength of the association based on Cramer's V [47].

\begin{tabular}{ccccc}
\hline Categorical Variable & $\mathbf{X}^{\mathbf{2}}$ & $\mathbf{d f}$ & $\boldsymbol{p}$-Value & Cramer's V \\
\hline Geographic Area Coordination Center & 111.5 & 24 & $<0.001$ & 0.45 \\
Resource type & 86.0 & 15 & $<0.001$ & 0.40 \\
Incident phase & 22.2 & 6 & 0.001 & 0.27 \\
\hline
\end{tabular}

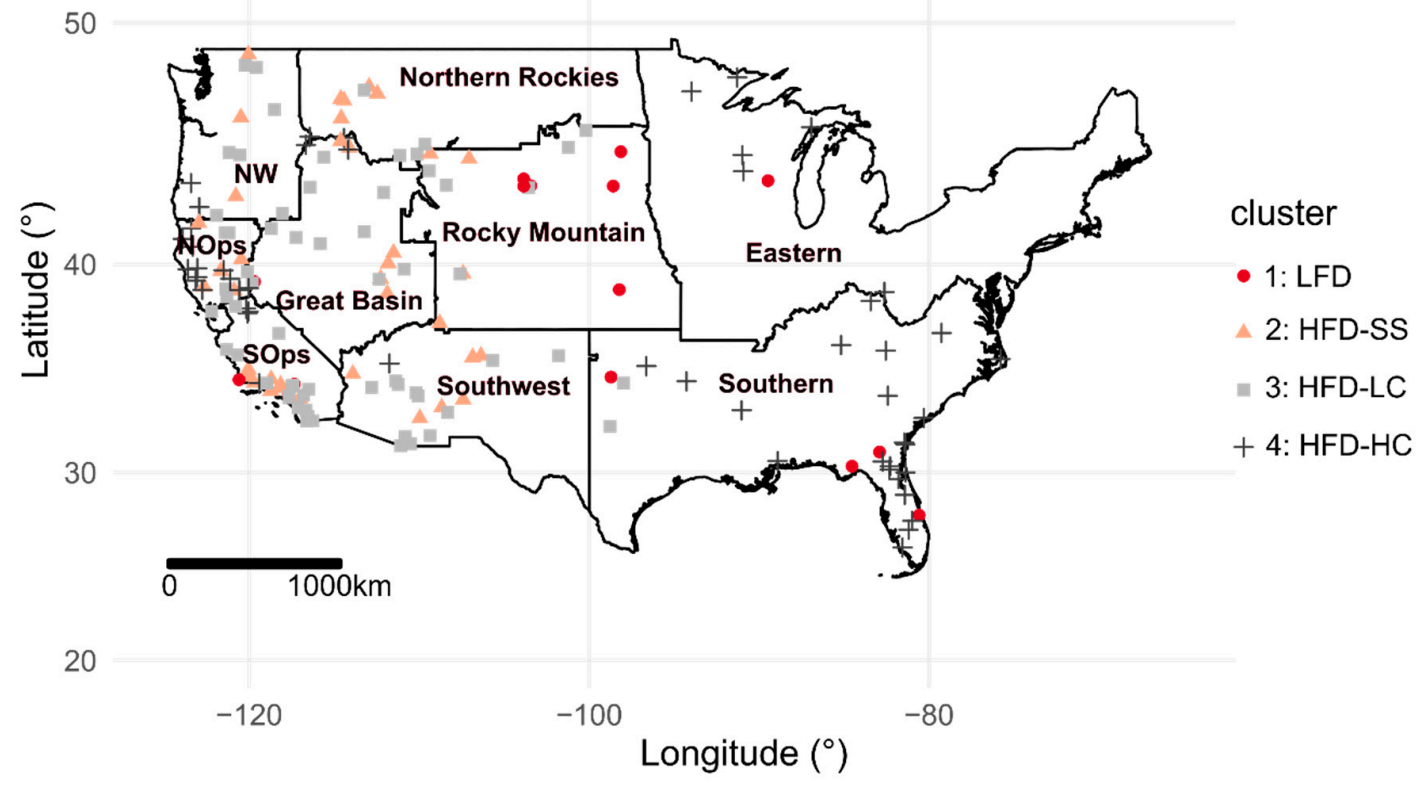

Figure 7. Locations of 166 US wildland firefighter entrapments (1981-2017) by cluster type and Geographic Area Coordination Center (GACC). The abbreviated GACCs include the Northwest (NW), North Ops (NOps), and South Ops (SOps).

The type of resource involved in the entrapment as well as the incident phase during the time of the entrapment were both significantly associated with cluster type. Entrapments within HFD-LC were positively associated with Engines and negatively associated with Equipment. Conversely, entrapments within HFD-HC were negatively associated with Engines and positively associated with Equipment (Figure 8). Additionally, entrapments within LFD were positively associated with prescribed fires, and entrapments within HFD-SS were positively associated with extended attack and negatively associated with initial attack (Figure 9). 


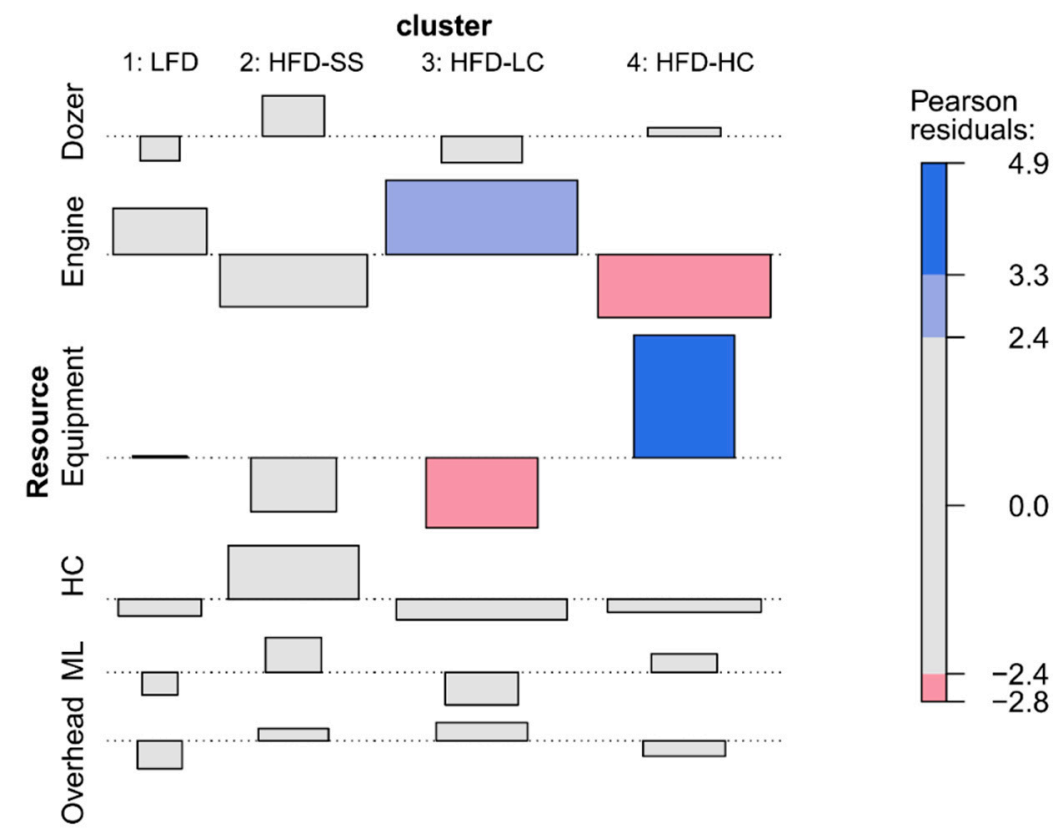

Figure 8. Association plot showing deviations from independence between the type of resource involved in the entrapment and cluster type. Light and dark blue shading corresponds to significant positive associations, $\alpha=0.05$ and $\alpha=0.0001$ respectively, while light red indicates a significant negative association $(\alpha=0.05)$ and grey is non-significant. The height of each rectangle is proportional to the corresponding Pearson residual (legend values) while the width is proportional to the square root of the expected count (i.e., wider indicates a higher expected value). The type of resource includes Hand Crews (HC) and multiple types (ML). Note that Equipment comprises non-dozer related firefighting equipment including tractor plows.

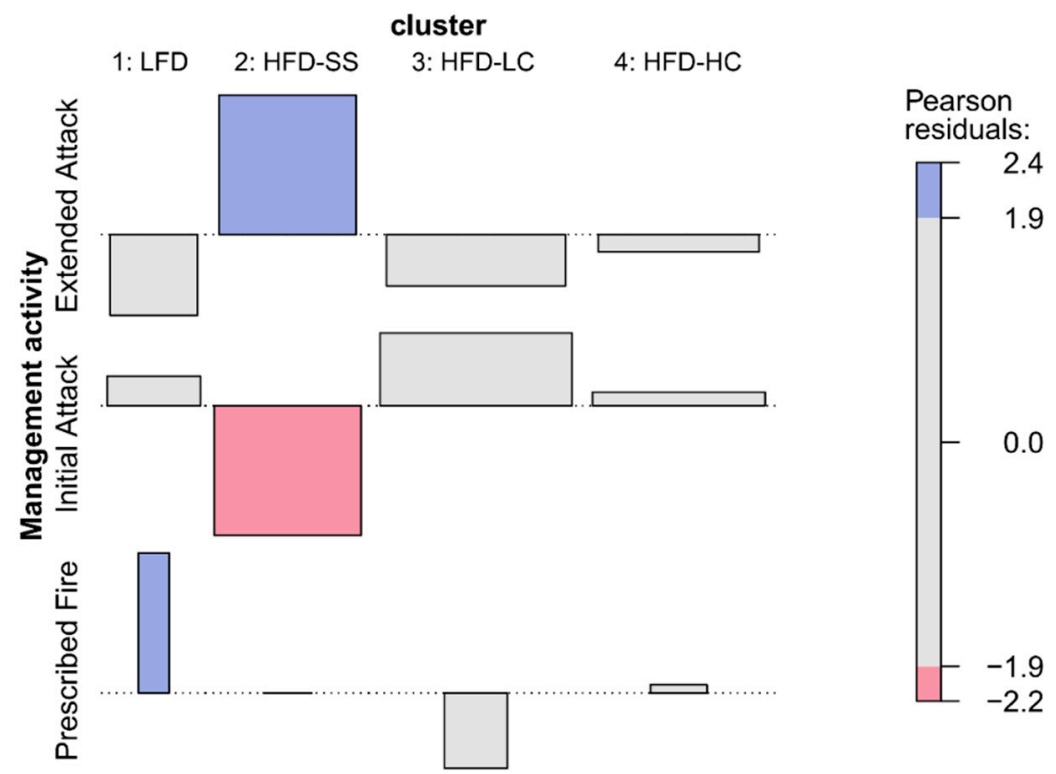

Figure 9. Association plot showing deviations from independence between the incident phase (Management activity) during the time of the entrapment and the cluster type. Light blue shading corresponds to a significant positive association $(\alpha=0.05)$, while light red indicates a significant negative association $(\alpha=0.05)$ and grey is non-significant. The height of each rectangle is proportional to the corresponding Pearson residual (legend values) while the width is proportional to the square root of the expected count (i.e., wider indicates a higher expected value). 


\subsection{Frequency Analysis}

\subsubsection{Fire Occurrence Database and MTBS}

Reported wildfires in the FOD were primarily classified has having environmental conditions similar to those of HFD-HC. Specifically, of the total reported wildfires from 1992 to 2017 in CONUS, about $61 \%$ had environmental conditions, at the fire start location and during the day of discovery, that were similar to firefighter entrapments within HFD-HC. Fires with environmental conditions similar to entrapments within HFD-SS were the rarest with only about $6 \%$ of the total fires meeting the pertinent criteria. The environmental conditions associated with entrapments within LFD and HFD-LC occurred on approximately 16 and $17 \%$ of the fires, respectively. The Eastern, Southern, North Ops, and Northwest GACCs had the majority of their fires classified as HFD-HC (Figure 10a). The Southwest, Great Basin, southern California (South Ops), Rocky Mountain, and Northern Rockies GACCs had the majority of fires similar to the HFD-LC entrapment environmental conditions.
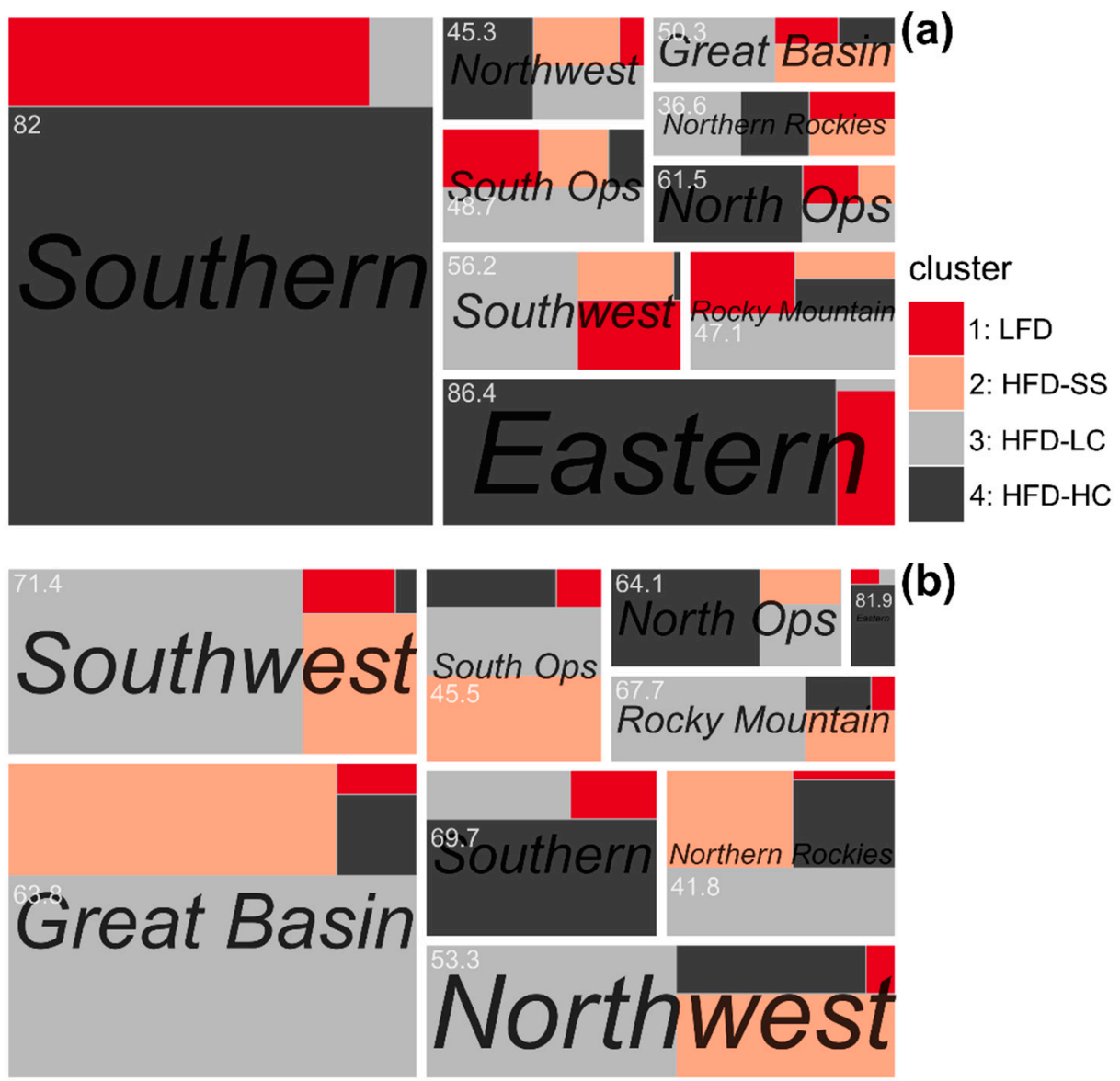

Figure 10. Treemap showing the proportional area of the number of fires (a) and area burned (b), relative to the total number of fires (1992-2017) and total area burned (1984-2017), respectively, by cluster type for each Geographic Area Coordination Center (GACC). The value of the cluster with the highest proportion (\%), relative to each GACC, is shown in the upper left-hand corner.

The environmental conditions within the MTBS large wildfire perimeters were primarily classified as similar to those of entrapments within HFD-LC (Figure 10b). The Rocky Mountain, Southwest, Great Basin, and Northwest GACCs each had on average large wildfires with more than $50 \%$ of the area within their perimeters classified as similar to HFD-LC. The environmental conditions similar to entrapments classified as HFD-HC were the most common within large fire perimeters located in the Eastern, Southern, and northern California (North Ops) GACCs. 


\subsubsection{CONUS}

At the scale of CONUS, the proportion of days and locations that had environmental conditions that were similar to previous wildland firefighter entrapments varied substantially by cluster type (Figure 11). Locations with similar fuel and topography to entrapments within the HFD-LC and HFD-HC clusters were widespread, occupying approximately 35 and $56 \%$ of the area in CONUS, respectively (Figure 11c,d). However, the times when those locations had similar fire danger conditions to entrapments were much less common, generally occurring on less than $20 \%$ of the days between 1981 and 2017. Conversely, locations with similar fuel and topography to entrapments within the LFD and HFD-SS were quite rare, occupying approximately 3 and $6 \%$ of the area within CONUS, respectively (Figure 11a,b). The times when locations classified as LFD had fire danger conditions similar to those during the entrapments were, however, quite common, generally occurring on about $50 \%$ or more of the days between 1981 and 2017. Locations classified as HFD-SS only had fire danger conditions similar to those during the entrapments on less than $20 \%$ of the days between 1981 and 2017.
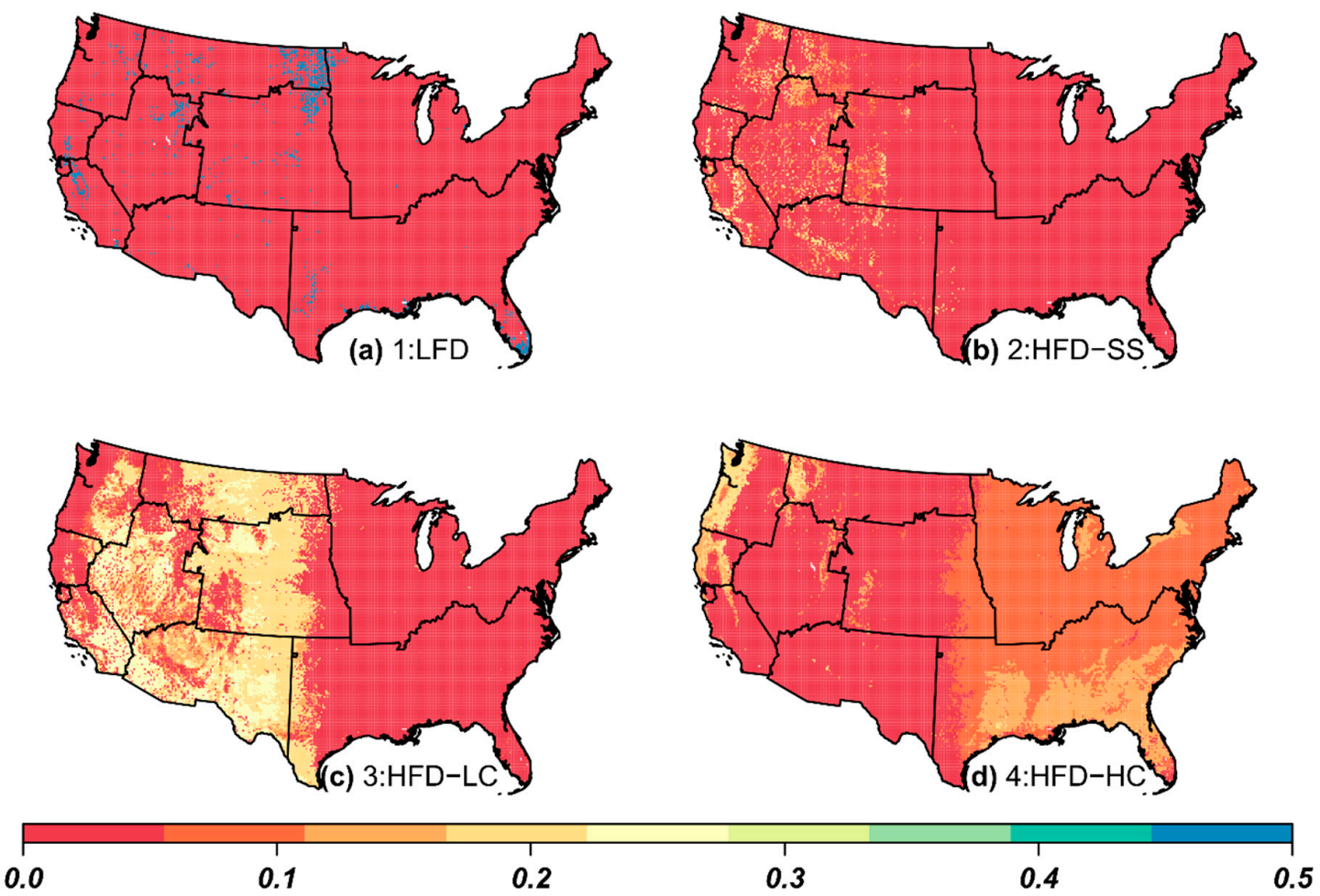

Figure 11. Proportion of days between 1981 and 2017 that were classified as having environmental conditions similar to firefighter entrapments within cluster 1 (LFD) (a), cluster 2 (HFD-SS) (b), cluster 3 (HFD-LC) (c), and cluster 4 (HFD-HC) (d).

\section{Discussion}

The environmental conditions associated with US wildland firefighter entrapments varied more than originally anticipated. Although several of the previously published firefighter safety guidelines were corroborated by our results, particularly the existence of a critical period between 1400 and 1700 local time and the importance of steep slopes [6], at the scale of CONUS, entrapments actually occur under a broad range of conditions. Additional statistical analysis indicated that unique sets of environmental characteristics related to firefighter entrapments can be identified, which define four archetypes that typify the times and locations where firefighter entrapments occur. Two of the archetypes are common geographically but rare temporally (HFD-LC and HFD-HC), while the other two archetypes are rare geographically and common (LFD) and rare (HFD-SS) temporally. 


\subsection{Common Environmental Conditions}

Of the 166 firefighter entrapment incidents that occurred within CONUS between 1981 and 2017, $15(9 \%)$ were identified as belonging to the LFD group, which in total involved 97 (8\%) firefighters and two (2\%) fatalities. Example entrapments include the New Holland Rx in South Dakota (2006) [52] and Burn Unit 233 in Florida (2012) [53]. The environmental conditions associated with these entrapments were primarily defined by the fire danger conditions on the day of the entrapment, generally occurring when the ERC' and $\mathrm{BI}^{\prime}$ values were less than the 70th percentile. Although the fuel and topographic characteristics associated with these entrapments appear to be rare (Figure 11a), in reality, they substantially overlapped with those of the other entrapment clusters (Table 4). These entrapments represent an anomaly within our current understanding of the environmental conditions that are considered dangerous to firefighters, as they occurred when fire danger was indicative of relatively benign fire weather [54-56]. Their positive association with prescribed fires suggests that several additional non-environmental characteristics may better define these types of entrapments. For example, prescribed fires utilize complex firing patterns to actively manipulate fire behavior to achieve different fire effects [57], which may have contributed to unexpected changes that surprised the affected firefighters. Additionally, several human factors (e.g., sleep deprivation [58], leadership skills, and situational awareness [59]) may have been more relevant to these entrapments than any specific environmental condition.

Thirty-seven (22\%) entrapment incidents accounting for a total of 439 (37\%) firefighters and $31(26 \%)$ fatalities were identified as belonging to the HFD-SS group. These entrapments occurred during high fire danger and at locations with steep slopes, with about $75 \%$ having ERC' values greater than the 80th percentile and slopes greater than $12^{\circ}[21 \%]\left(\max 38^{\circ}\right.$ [78\%]). Example entrapments include the South Canyon Fire in Colorado (1994) [60] and the Cramer Fire in Idaho (2003) [61]. Additionally, these entrapments tended to involve the highest number of firefighters per incident and were positively associated with extended attack fires. The environmental conditions that define these entrapments were rare both geographically and temporally, mostly occurring within the western GACCs. Although the times and locations where fires started within CONUS between 1992 and 2017 were seldom classified as having environmental conditions similar to those of HFD-SS entrapments, a high proportion of the area within large fire perimeters in the western GACCs, especially in southern California (South Ops), did have similar conditions. Southern California has an extensive history of firefighter entrapments [1,62-65], with previous work showing a strong relationship between slope steepness and both the likelihood of an entrapment and subsequent fatalities [66,67].

A total of 63 (38\%) entrapment incidents that affected a total of 346 (29\%) firefighters with 69 (59\%) fatalities were characterized as belonging to the HFD-LC group. Fire danger conditions on the day of these entrapments were high, with 75\% occurring when the ERC' and $\mathrm{BI}^{\prime}$ values were greater than the 92nd and 81st percentiles, respectively. Additionally, these entrapments primarily took place within the western GACCs, on relatively flat slopes $\left(<8^{\circ}[14 \%]\right)$, where annual precipitation (precip) was less than $759 \mathrm{~mm} \mathrm{yr}^{-1}$, and were significantly associated with firefighters working on Engines. The static environmental conditions (topography and fuels) associated with these entrapments are widespread in the western US, but the dynamic conditions are rare. The precip and maxNDVI values linked to these entrapments suggest that these locations most likely represent vegetation conditions typical of grasslands [68], shrub lands, or dry conifer forest types [69]. Several well-known entrapments had conditions that were typical of the cluster including, Oakland Hills (1991) [70], Esperanza (2006) [71], and Twisp River (2015) [72].

Entrapments classified as belonging to the HFD-HC group represented $51(31 \%)$ incidents, $320(27 \%)$ firefighters, and 15 (13\%) fatalities. Example entrapments include the Salt Fire in Idaho (2011) [73] and the Crane Island Fire in Florida (2017) [74]. Much like the entrapments associated with the HFD-LC group, the fire danger conditions on the day of the entrapment were high with $75 \%$ of the incidents having $\mathrm{ERC}^{\prime}$ and $\mathrm{BI}^{\prime}$ values above the 89th and 88th percentiles, respectively, and slopes less than $10^{\circ}[18 \%]$. Contrary to the HFD-LC entrapments, however, these incidents occurred at locations 
with relatively high precip and maxNDVI values. These high values combined with their positive association with firefighters working on Equipment (i.e., tractor plows) suggests that they are typical of the conditions associated with entrapments in timber-dominated fuel types, primarily in the Eastern and Southern GACCs, but also wetter areas, e.g., coastal forests or high-elevation areas, within the western GACCs.

\subsection{Practical Implications}

Given the findings of this study and previously published firefighter safety guidelines, we have identified a few key practical implications for wildland firefighters: (1) the fire environment conditions or subsequent fire behavior, particularly rate of spread, at the time of the entrapment does not need to be extreme or unusual for an entrapment to occur; it only needs to be unexpected in the sense that the firefighters involved did not anticipate or could not adapt to the observed fire behavior in enough time to reach an adequate safety zone [75]; (2) the site and regional-specific environmental conditions at the time and location of the entrapment are important; in other words, the set of environmental conditions common to firefighter entrapments in one region do not necessarily translate to other locations; (3) as noted by several authors [5,59,76,77], human factors or human behavior are a critical component of firefighter entrapments, so much so that while an analysis of the common environmental conditions associated with entrapments will yield a better understanding of the conditions that increase the likelihood of an entrapment, it will not produce models or define characteristics that predict where and when entrapments are likely to occur.

At first glance, many of the current firefighter safety guidelines related to entrapments, including those from Wilson [5] and the Look Up, Down, And Around training [10], seem to focus on identifying the environmental characteristics associated with extreme fire behavior [11]. However, upon further examination, it is evident that substantial emphasis is also placed on those characteristics that promote a rapid change in fire behavior. Changes in wind speed or direction, slope reversals, and the ability of fires burning in light, grassy fuels to rapidly increase in spread rate have been noted as contributing factors in previous entrapments $[5,14,21,22,78,79]$. It is both the unexpected nature of the change in fire behavior coupled with the inability of firefighters to adapt to the observed fire behavior given their current situation, as, for example, during equipment malfunctions or breakdowns, that ultimately leads to entrapment $[23,80]$. In this study, we were not able to temporally resolve rapid changes in wind speed or wind direction, but our findings indicate that their influence on entrapment potential is stronger when fire danger is high relative to historical conditions. Based on these findings, we propose that the current suite of firefighter safety guidelines related to entrapment potential are still largely valid, however, we caution against an over-emphasis on those guidelines that focus only on the potential for extreme fire behavior and argue for increased recognition that the environmental conditions capable of resulting in an entrapment are much broader than previously acknowledged.

Although it is apparent at the scale of CONUS that entrapments are possible under a wide range of environmental conditions, at smaller spatial scales with more site-specific context, there are several characteristics that define entrapment archetypes or the typical conditions associated with entrapments. We identified four entrapment archetypes that were best described by the fire danger conditions during the day of the entrapment, slope steepness, annual precipitation, and maximum potential greenness. The finding that there is site and regional-specific variation among the common environmental conditions associated with entrapments suggests that it may be unwise to assume that a fixed set of common denominators are applicable at all locations and all times. This is true both across CONUS and other parts of the world, as it is expected that site and regional-specific variability in the environmental conditions that influence fire occurrence, fire behavior, and fire suppression operations will affect what defines dangerous conditions for firefighters. Thus, we do not anticipate that the specific findings presented in this study will be broadly applicable to areas outside of CONUS, although we do expect general commonalities related to the importance of hot, dry, and windy conditions $[18,19,81,82]$. 
The one characteristic that was common for the majority of entrapments ( $91 \%)$ was high fire danger. As a general guideline, regardless of location, the data suggest that entrapment potential is highest when the fire danger indices (ERC' and $\mathrm{BI}^{\prime}$ ) are both above their historical 80th percentile. Until recently, spatially-explicit information on fire danger has not been widely available as most firefighters have relied on fire danger information available at specific weather stations, which are often summarized into Pocket Cards [83]. Fortunately, fire danger forecasts across CONUS are now available in a mobile-friendly format (see https://m.wfas.net) that can be displayed spatially for each of the fire danger indices separately or combined into a Severe Fire Danger Index [27].

Several non-environmental characteristics that were not evaluated in this study, including those related to human behavior, likely have significant impacts on entrapment potential [59] that may override any specific set of environmental conditions. The human aspect of wildland firefighting includes a broad range of factors that have been studied in a variety of disciplines, including psychology, management, and communications [84]. Understanding the role of these non-environmental factors on firefighter entrapments to improve organizational learning has been difficult for a variety of reasons, but continued work in this field is encouraging $[85,86]$. It is hoped that future work related to human factors employs rigorous, quantitatively-based assessments that allow for the identification of specific and objective criteria that influence entrapment potential.

\section{Conclusions}

The times and locations where wildland firefighter entrapments occur in the US cover a wide range of conditions. Current firefighter safety guidelines seem to emphasize only a subset of the possible conditions due to a focus on the factors that maximize the potential for extreme fire behavior. While many of these safety guidelines are still intuitively valid (e.g., Wilson [5]), caution should be exercised during relevant firefighter training so as to not ignore or undermine the fact that entrapments and fatalities are possible under a much wider range of conditions. Despite the wide range of environmental conditions associated with entrapments, we have shown that it is possible to identify unique combinations of environmental variables to define similarities among groups of entrapments, but these will necessarily be context and site specific. For most entrapments, the only common environmental condition was high fire danger, as represented by fire danger indices that have been normalized to represent the historical percentile at a particular location. As such, at large spatial scales, fire danger and its association with fire weather should continue to be monitored and reported to firefighters using both traditional methods (i.e., morning fire weather forecasts) and also newer methods that take advantage of advancements in mobile technology.

Author Contributions: Conceptualization, W.G.P., P.H.F., B.W.B., and W.M.J.; Methodology, W.G.P. and P.H.F.; formal analysis, W.G.P. and P.H.F.; writing-original draft preparation, W.G.P.; writing-review and editing, P.H.F., B.W.B., and W.M.J.; funding acquisition, B.W.B. and W.M.J.

Funding: This research was funded by the USDA Forest Service National Fire Plan through the Washington Office of the Forest Service Deputy Chief for Research and the Joint Fire Science Program, Project 18-S-01-1.

Acknowledgments: We gratefully acknowledge review of the manuscript by M. E. Alexander and three anonymous reviewers.

Conflicts of Interest: The authors declare no conflict of interest. 


\section{Appendix A}
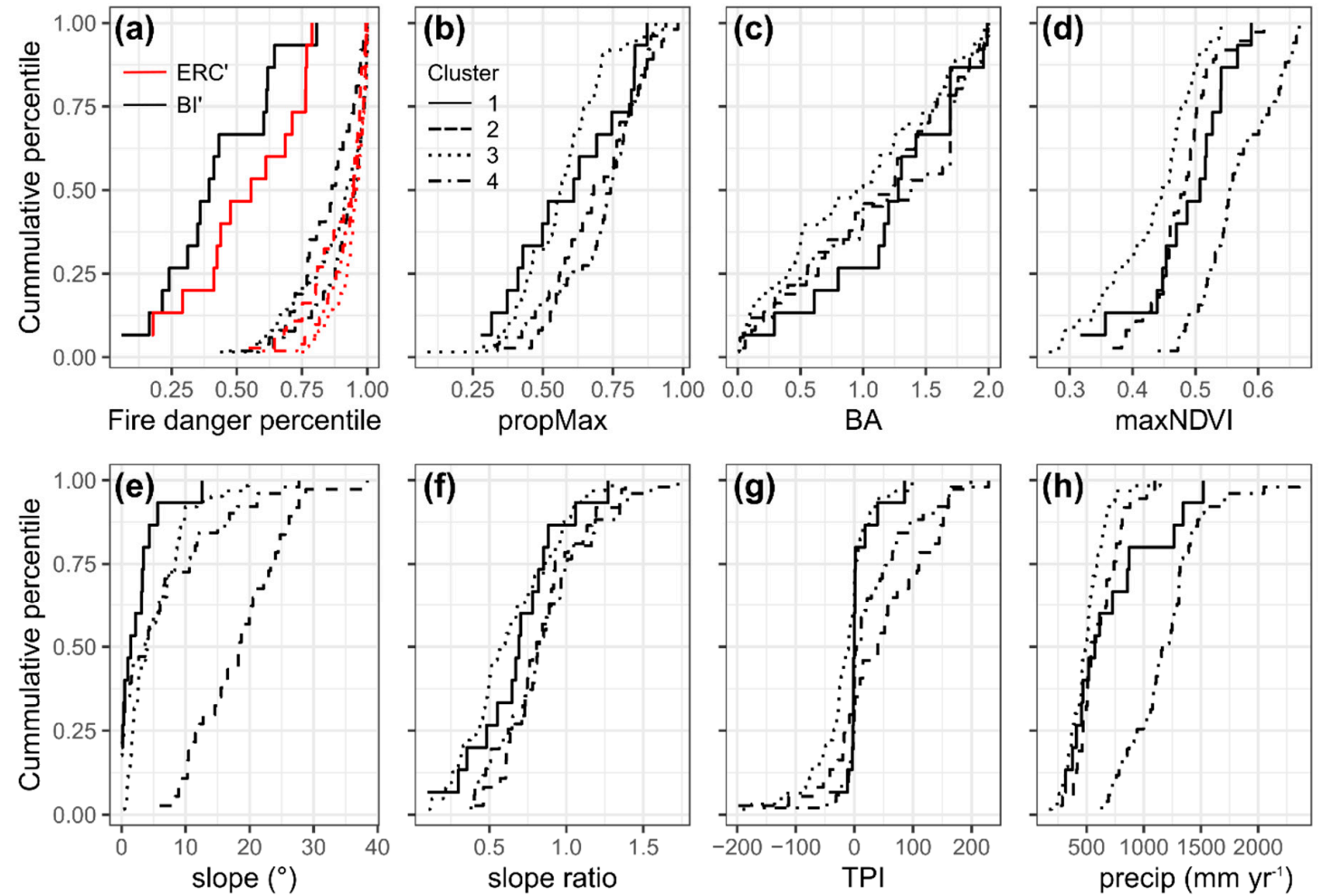

Figure A1. Cumulative percentile distributions by cluster type; cluster 1 (solid line), cluster 2 (dashed line), cluster 3 (dotted line), and cluster 4 (dot-dash line). Data represent distributions for each of the environmental variables $(\mathbf{a}-\mathbf{h})$ at the times and locations of 166 wildland firefighter entrapments that occurred within CONUS (1981-2017). See Table 2 for variable definitions.

\section{References}

1. Moore, W.R.; Parker, V.A.; Countryman, C.M.; Mays, L.K.; Greeley, A.W. Report of Task Force to Recommend Action to Reduce the Chances of Men being Killed by Burning while Fighting Fire; U.S. Department of Agriculture, Forest Service: Washington, DC, USA, 1957; p. 30.

2. Bjornsen, R.; Peterson, J.; Skufca, T.; Hardy, M.; Spaulding, A.E. A Plan to Further Reduce the Chances of Men being Burned while Fighting Fires; U.S. Department of Agriculture, Forest Service: Washington, DC, USA, 1967; p. 76.

3. National Wildfire Coordinating Group. Preliminary Report of Task Force on Study of Fatal/Near-Fatal Wildland Fire Accidents; Boise Interagency Fire Center: Boise, ID, USA, 1980; p. 53.

4. McArdle, R.E. Standard fire fighting orders. Fire Control Notes 1957, 18, 151.

5. Wilson, C.C. Fatal and near-fatal forest fires: The common denominators. Int. Fire Chief 1977, 43, 9-10, 12-15.

6. National Wildfire Coordinating Group. Incident Response Pocket Guide; PMS 461/NFES 1077; National Interagency Fire Center: Boise, ID, USA, 2018; p. 120.

7. Gleason, P. LCES-A key to safety in the wildland fire environment. Fire Manag. Notes 1991, $52,9$.

8. Munson, S.; Mangan, D. Wildland Firefighter Entrapments 1976 to 1999; Technical Report 9751-2817-MTDC; U.S. Department of Agriculture, Forest Service, Missoula Technology Development Center: Missoula, MT, USA, 2000; p. 10.

9. Mangan, R. Wildland Firefighter Fatalities in the United States: 1990-2006; PMS 841; National Interagency Fire Center: Boise, ID, USA, 2007; p. 28.

10. National Wildfire Coordinating Group. Look Up, Look Down, Look Around; Boise Interagency Fire Center: Boise, ID, USA, 1992; p. 15. 
11. Werth, P.A.; Potter, B.E.; Clements, C.B.; Finney, M.A.; Goodrick, S.L.; Alexander, M.E.; Cruz, M.G.; Forthofer, J.M.; McAllister, S.S. Synthesis of Knowledge of Extreme Fire Behavior: Volume I for Fire Managers; U.S. Department of Agriculture, Forest Service, Pacific Northwest Research Station: Portland, OR, USA, 2011; p. 144. [CrossRef]

12. Werth, P.A.; Potter, B.E.; Alexander, M.E.; Cruz, M.G.; Clements, C.B.; Finney, M.A.; Forthofer, J.M.; Goodrick, S.L.; Hoffman, C.; Jolly, W.M.; et al. Synthesis of Knowledge of Extreme Fire Behavior: Volume 2 for Fire Behavior Specialists, Researchers, and Meteorologists; U.S. Department of Agriculture, Forest Service, Pacific Northwest Research Station: Portland, OR, USA, 2016; p. 258.

13. Arnold, R.K.; Buck, C.C. Blow-up fires-Silviculture or weather problems? J. For. 1954, 52, $408-411$. [CrossRef]

14. Viegas, D.X. Parametric study of an eruptive fire behaviour model. Int. J. Wildl. Fire 2006, 15, 169-177. [CrossRef]

15. Chatelon, F.J.; Sauvagnargues, S.; Dusserre, G.; Balbi, J.H. Generalized blaze flash, a "flashover" behavior for forest fires-Analysis from the firefighter's point of view. Open J. For. 2014, 4, 547-557. [CrossRef]

16. Balbi, J.H.; Chatelon, F.J.; Rossi, J.L.; Simeoni, A.; Viegas, D.X.; Rossa, C. Modelling of eruptive fire occurrence and behaviour. J. Environ. Sci. Eng. B 2014, 3, 115-132.

17. Viegas, D.X.; Simeoni, A. Eruptive behaviour of forest fires. Fire Technol. 2011, 47, 303-320. [CrossRef]

18. Lahaye, S.; Sharples, J.; Matthews, S.; Heemstra, S.; Price, O.; Badlan, R. How do weather and terrain contribute to firefighter entrapments in Australia? Int. J. Wildl. Fire 2018, 27, 85-98. [CrossRef]

19. Lahaye, S.; Curt, T.; Fréjaville, T.; Sharples, J.; Paradis, L.; Hély, C. What are the drivers of dangerous fires in Mediterranean France? Int. J. Wildl. Fire 2018, 27, 155-163. [CrossRef]

20. Viegas, D.X.; Pita, L.P.; Ribeiro, L.; Palheiro, P. Eruptive fire behaviour in past fatal accidents. In Proceedings of the Eighth International Wildland Fire Safety Summit: Human Factors-10 Years Later, Missoula, MT, USA, 26-28 April 2005.

21. Page, W.G.; Freeborn, P.H.; Butler, B.W.; Jolly, W.M. A review of US wildland firefighter entrapments: Trends, important environmental factors and research needs. Int. J. Wildl. Fire 2019, 28, 551-569. [CrossRef]

22. Bishop, J. Technical background of the FireLine Assessment MEthod (FLAME). In Proceedings of the Fire Environment-Inovations, Management, and Policy; Conference Proceedings, Destin, FL, USA, 26-30 March 2007.

23. National Wildfire Coordinating Group. Glossary of Wildland Fire Terminology; National Interagency Fire Center: Boise, ID, USA, 2006; p. 183.

24. PRISM Climate Group, Oregon State University, Climate Data. 2004. Available online: http://prism. oregonstate.edu/ (accessed on 22 August 2019).

25. Rollins, M.G. LANDFIRE: A nationally consistent vegetation, wildland fire, and fuel assessment. Int. J. Wildl. Fire 2009, 18, 235-249. [CrossRef]

26. NOAA Center for Satellite Applications and Research, STAR—Global vegetation health products. Available online: https://www.star.nesdis.noaa.gov/smcd/emb/vci/VH/vh_ftp.php (accessed on 22 August 2019).

27. Jolly, W.M.; Freeborn, P.H.; Page, W.G.; Butler, B.W. Severe fire danger index: A forecastable metric to inform firefighter and community wildfire risk management. Fire 2019, 2, 47. [CrossRef]

28. Newnham, G.J.; Verbesselt, J.; Grant, I.F.; Anderson, S.A.J. Relative greenness index for assessing curing of grassland fuel. Remote Sens. Environ. 2011, 115, 1456-1463. [CrossRef]

29. Jenness, J. Topographic Position Index (tpi_jen.avx) extension for ArcView 3.x, v. 1.3a, 2006; Jenness Enterprises. Available online: http://www.jennessent.com/arcview/tpi.htm (accessed on 22 August 2019).

30. Bradshaw, L.S.; Deeming, J.E.; Burgan, R.E.; Cohen, J.D. The 1978 National Fire-Danger Rating System: Technical Documentation; Gen. Tech. Rep. INT-GTR-169; U.S. Department of Agriculture, Forest Service, Intermountain Forest and Range Experiment Station: Ogden, UT, USA, 1984; p. 44.

31. Beers, T.W.; Dress, P.E.; Wensel, L.C. Aspect transformation in site productivity research. J. For. 1966, 64, 691-692. [CrossRef]

32. Goward, S.N.; Dye, D.G. Evaluating North American net primary productivity with satellite observations. Adv. Sp. Res. 1987, 7, 165-174. [CrossRef]

33. Petrie, M.D.; Peters, D.P.C.; Yao, J.; Blair, J.M.; Burruss, N.D.; Collins, S.L.; Derner, J.D.; Gherardi, L.A.; Hendrickson, J.R.; Sala, O.E.; et al. Regional grassland productivity responses to precipitation during multiyear above- and below-average rainfall periods. Glob. Chang. Biol. 2018, 24, 1935-1951. [CrossRef] 
34. Zhang, X.; Wu, S.; Yan, X.; Chen, Z. A global classification of vegetation based on NDVI, rainfall and temperature. Int. J. Climatol. 2017, 37, 2318-2324. [CrossRef]

35. Burgan, R.E.; Hartford, R.A.; Eidenshink, J.C. Using NDVI to Assess Departure from Average Greenness and its Relation to Fire Business; U.S. Department of Agriculture, Forest Service, Intermountain Research Station: Ogden, UT, USA, 1996; p. 8. [CrossRef]

36. Short, K.C. A spatial database of wildfires in the United States, 1992-2011. Earth Syst. Sci. Data 2014, 6, 1-27. [CrossRef]

37. Eidenshink, J.; Schwind, B.; Brewer, K.; Zhu, Z.; Quayle, B.; Howard, S. A project for monitoring trends in burn severity. Fire Ecol. 2007, 3, 3-21. [CrossRef]

38. Chang, F.; Qiu, W.; Zamar, R.H.; Lazarus, R.; Wang, X. clues: An R package for nonparametric clustering based on local shrinking. J. Stat. Softw. 2010, 33, 1-16. [CrossRef]

39. R Core Team. R: A Language and Environment for Statistical Computing; R Foundation for Statistical Computing: Vienna, Austria, 2018; Available online: https://www.r-project.org/ (accessed on 22 August 2019).

40. Rousseeuw, P.J. Silhouettes: A graphical aid to the interpretation and validation of cluster analysis. J. Comput. Appl. Math. 1987, 20, 53-65. [CrossRef]

41. Hartigan, J.A.; Wong, M.A. A K-means clustering algorithm. Appl. Stat. 1979, 28, 100-108. [CrossRef]

42. Kaufman, L.; Rousseeuw, P.J. Finding Groups in Data: An Introduction to Cluster Analysis; John Wiley \& Sons, Ltd.: New York, NY, USA, 1990.

43. Kruskal, W.H.; Wallis, A. Use of ranks in one-criterion variance analysis. J. Am. Stat. Assoc. 1952, 47, 583-621. [CrossRef]

44. Dunn, O.J. Multiple comparisons using rank sums. Technometrics 1964, 6, 241-252. [CrossRef]

45. Benjamini, Y.; Hochberg, Y. Controlling the false discovery rate: A practical and powerful aproach to multiple testing. J. R. Stat. Soc. 1995, 57, 289-300. [CrossRef]

46. Meyer, D.; Zeileis, A.; Hornik, K. vcd: Visualizing categorical data. R package version 1.4-4. Available online: https://cran.r-project.org/web/packages/vcd/ (accessed on 22 August 2019).

47. Cramér, H. Mathematical Methods of Statistics; Princeton University Press: Princeton, NJ, USA, 1946.

48. Meyer, D.; Zeileis, A.; Hornik, K. The strucplot framework: Visualizing multi-way contingency tables with vcd. J. Stat. Softw. 2006, 17, 1-48. [CrossRef]

49. Breiman, L. Random Forests. Mach. Learn. 2001, 45, 5-32. [CrossRef]

50. Ishwaran, H.; Kogalur, U.B. randomForestSRC: Fast Unified Random Forests for Survival, Regression, and Classification (RF-SRC). R Package Version 2.9.1. Available online: https://cran.r-project.org/web/packages/ randomForestSRC/ (accessed on 22 August 2019).

51. Therneau, T.; Atkinson, B.; Ripley, B. rpart: Recursive Partitioning and Regression Trees. R Package Version 4.1-15. Available online: https://cran.r-project.org/web/packages/rpart/index.html (accessed on 22 August 2019).

52. Morford, D.L.; Melvin, C.; Wimberly, F.; Segar, J. New Holland Prescribed Fire: Escaped Prescribed Fire Review; U.S. Department of Interior, Fish and Wildlife Service, Lake Andes National Wildlife Refuge: New Holland, SD, USA, 2006; p. 58.

53. Way, F.; Engrav, T.; Harris, J.; Dabney, T. Burn Unit 233 Entrapment; U.S. Department of Agriculture, Forest Service, Apalachicola National Forest: Tallahassee, FL, USA, 2012; p. 11.

54. Heinsch, F.A.; Andrews, P.L.; Kurth, L.L. Implications of using percentiles to define fire danger levels: Extended abstract. In Proceedings of the Eighth Symposium on Fire and Forest Meteorology, Kalispell, MT, USA, 12-15 October 2009.

55. Freeborn, P.H.; Cochrane, M.A.; Jolly, W.M. Relationships between fire danger and the daily number and daily growth of active incidents burning in the northern Rocky Mountains, USA. Int. J. Wildl. Fire. 2016, 24, 900-910. [CrossRef]

56. Andrews, P.L.; Loftsgaarden, D.O.; Bradshaw, L.S. Evaluation of fire danger rating indexes using logistic regression and percentile analysis. Int. J. Wildl. Fire 2003, 12, 213-226. [CrossRef]

57. Rothermel, R.C. Fire behavior consideration of aerial ignition. In Proceedings of the Prescribed Fire by Aerial Ignition, Proceedings of a Workshop, Missoula, MT, USA, 30 October-1 November 1984.

58. Vincent, G.E.; Aisbett, B.; Wolkow, A.; Jay, S.M.; Ridgers, N.D.; Ferguson, S.A. Sleep in wildland firefighters: What do we know and why does it matter? Int. J. Wildl. Fire 2018, 27, 73-84. [CrossRef] 
59. Putnam, T. Findings from the Wildland Firefighters Human Factors Workshop; Technical Report 9551-2855-MTDC; U.S. Department of Agriculture, Forest Service, Missoula Technology Development Center: Missoula, MT, USA, 1996; p. 75.

60. Rosenkrance, L.K.; Reimers, M.A.; Johnson, R.A.; Webb, J.B.; Graber, J.H.; Clarkson, M.; Werth, P.; Husari, S.; Mangan, D. Report of the South Canyon Fire Accident Investigation Team; U.S. Department of Interior, Bureau of Land Management and U.S. Department of Agriculture, Forest Service: Washington, DC, USA, 1994; p. 39.

61. Donoghue, L.; Jackson, G.; Angel, R.; Beebe, G.; Bishop, K.; Close, K.; Moore, R.; Newman, E.; Schmidt, M.; Whitlock, C. Accident Investigation Factual Report: Cramer Fire Fatalities, North Fork Ranger District, Salmon-Challis National Forest, Region 4; 0351-2M48-MTDC; U.S. Department of Agriculture, Forest Service, Missoula Technology \& Development Program: Missoula, MT, USA, 2003; p. 70.

62. U.S. Department of Agriculture, Forest Service. The Inaja Forest Fire Disaster: Cleveland National Forest, California; U.S. Department of Agriculture, Forest Service: Washington, DC, USA, 1957; p. 6.

63. Schroeder, M.J.; Taylor, B.B. Inaja Fire-1956, Pine Hills Fire-1967... Similar, Yet Different; U.S. Department of Agriculture, Forest Service, Pacific Southwest Research Station: Berkeley, CA, USA, 1968; p. 7.

64. Countryman, C.M.; Fosberg, M.A.; Rothermel, R.C.; Schroeder, M.J. Fire weather and fire behavior in the 1966 Loop fire. Fire Technol. 1968, 4, 126-141. [CrossRef]

65. Countryman, C.M.; McCutchan, M.H.; Ryan, B.C. Fire Weather and Fire Behavior at the 1968 Canyon Fire; U.S. Department of Agriculture, Forest Service, Pacific Southwest Forest and Range Experiment Station: Berkeley, CA, USA, 1969; p. 20.

66. Page, W.G.; Butler, B.W. Fuel and topographic influences on wildland firefighter burnover fatalities in Southern California. Int. J. Wildl. Fire 2018, 27, 141-154. [CrossRef]

67. Page, W.G.; Butler, B.W. An empirically based approach to defining wildland firefighter safety and survival zone separation distances. Int. J. Wildl. Fire 2017, 26, 655-667. [CrossRef]

68. Brown, D.E.; Makings, E. A guide to North American grasslands. Desert Plants 2014, 29, 1-160.

69. Thompson, R.S.; Anderson, K.H.; Pelltier, R.T.; Strickland, L.E.; Shafer, S.L.; Bartlein, P.J. Atlas of Relations between Climatic Parameters and Distributions of Important Trees and Shrubs in North America-Revisions for all Taxa from the United States and Canada and New Taxa from the Western United States; U.S. Department of Interior, Geological Survey: Reston, VA, USA, 2015. [CrossRef]

70. Teague, P.E. The Oakland/Berkeley Hills Fire: October 20, 1991; National Fire Protection Association: Quincy, MA, USA, 1991; p. 22.

71. Esperanza Investigation Team. Esperanza Fire Accident Investigation Factual Report, Riverside County, California, October 26, 2006; U.S. Department of Agriculture, Forest Service and California Department of Forestry and Fire Protection: Riverside County, CA, USA, 2007; p. 118.

72. U.S. Department of Agriculture, Forest Service. Twisp River Fire Fatalities and Entrapments: Learning Review Narrative; U.S. Department of Agriculture, Forest Service: Washington, DC, USA, 2016; p. 44.

73. Church, S.; Romero, F.; Erskine, I.; Evans, L.A.; Camper, D.; Petrilli, A. Salt Fire-August 29, 2011: USDA Forest Service, Intermountain Region 4, Salmon-Challis National Forest, Facilitated Learning Analysis of Entrapment, Shelter Deployment and Equipment Loss; U.S. Department of Agriculture, Forest Service, Salmon-Challis National Forest: Salmon, ID, USA, 2011; p. 31.

74. Grubbs, L.; Black, E.; Burns, A. Crane Island Fire: Facilitated Learning Analysis; Florida Forest Service: Tallahassee, FL, USA, 2017; p. 6.

75. Beighley, M. Beyond the safety zone: Creating a margin of safety. Fire Manag. Today 1995, 55, $21-24$.

76. Weick, K.E. Human factors in fire behavior analysis: Reconstructing the Dude fire. Fire Manag. Today 2002, 62, 8-15.

77. Weick, K.E. The collapse of sensemaking in organizations: The Mann Gulch disaster. Adm. Sci. Q. 1993, 38, 628-652. [CrossRef]

78. Cheney, N.P.; Gould, J.S.; McCaw, L. The Dead-Man Zone-a neglected area of firefighter safety. Aust. For. 2001, 64, 45-50. [CrossRef]

79. Alexander, M.E.; Fogarty, L.G. A Pocket Card for Predicting Fire Behaviour in Grasslands Under Severe Burning Conditions; Fire Technology Transfer Note 25; Forest Research and National Rural Fire Authority: Wellington, New Zealand, 2002; p. 8.

80. Page, W.G.; Freeborn, P.H. Entrapment. In Encyclopedia of Wildfires and Wildland-Urban Interface (WUI) Fires; Manzello, S.L., Ed.; Springer Nature: New York, NY, USA, 2019. [CrossRef] 
81. Blanchi, R.; Leonard, J.; Haynes, K.; Opie, K.; James, M.; Oliveira, F.D. Environmental circumstances surrounding bushfire fatalites in Australia 1901-2011. Environ. Sci. Pol. 2014, 37, 192-203. [CrossRef]

82. Cardil, A.; Molina, D.M. Factors causing victims of wildland fires in Spain (1980-2010). Hum. Ecol. Risk Assess. 2015, 21, 67-80. [CrossRef]

83. Andrews, P.L.; Bradshaw, L.S.; Bunnell, D.L.; Curcio, G.M. Fire danger rating pocket card for firefighter safety. In Proceedings of the 2nd Symposium on Fire and Forest Meteorology, Phoenix, AZ, USA, 11-16 January 1998.

84. Larson, G.; Wright, V.; Spaulding, C.; Rossetto, K.; Rausch, G.; Richards, A.; Durnford, S. Using Social Science to Understand and Improve Wildland Fire Organizations: An Annotated Readling List; U.S. Department of Agriculture, Forest Service, Rocky Mountain Research Station: Fort Collins, CO, USA, 2007; p. 82. [CrossRef]

85. Black, A.E.; Saveland, J.; Thomas, D.; Ziegler, J. Using Escaped Prescribed Fire Reviews to Improve Organizational Learning; U.S. Department of Interior and U.S. Department of Agriculture, Joint Fire Science Program: Boise, ID, USA, 2012; p. 31.

86. Black, A.E.; McBride, B.B. Assessing High Reliability Practices in Wildland Fire Management: An Exploration and Benchmarking of Organizational Culture; U.S. Department of Agriculture, Forest Service, Rocky Mountain Research Station: Fort Collins, CO, USA, 2013; p. 17. [CrossRef]

(C) 2019 by the authors. Licensee MDPI, Basel, Switzerland. This article is an open access article distributed under the terms and conditions of the Creative Commons Attribution (CC BY) license (http://creativecommons.org/licenses/by/4.0/). 